\title{
Disaccharide-Containing Macrocycles by Click Chemistry and Intramolecular Glycosylation
}

\author{
Vinod K. Tiwari, ${ }^{[a, b]}$ Amit Kumar, ${ }^{|a|}$ and Richard R. Schmidt ${ }^{*|a, c|}$
}

Keywords: Carbohydrates / Glycosylation / Macrocycles / Nitrogen heterocycles / Click chemistry

In this study $o$ - and $m$-xylylene moieties in combination with a triazolylmethyl moiety have been successfully employed as a relatively rigid spacer system in intramolecular glycosylation reactions. Phenyl 3,4,6-tri-O-benzyl-2-O-propargyl-1thio-D-glucopyranoside was employed as a donor, which could be readily connected by 1,3-dipolar cycloaddition (click reaction) to $\mathrm{O}$-(2- or 3-azidomethylbenzyl)-protected acceptors to afford, after liberation of the accepting hydroxy groups, the desired donor-spacer-acceptor-linked intermediates. NIS/TMSOTf-promoted glycosylation furnished disaccharide-containing macrocycles. In general, very good results were obtained. The anomeric selectivity is dependent on various factors, the ring size seeming crucial.

\section{Introduction}

Carbohydrate-based molecules play pivotal roles in many physiologically and pathologically important processes including cellular recognition, communication, cell growth regulation, cell differentiation, adhesion, migration, invasion, inflammation, immunological response, tumour metastasis and bacterial and viral infection, and hence the general interest in these compounds, particularly as constituents of glycoconjugates, has greatly increased in recent years. ${ }^{[1,2]}$ This increasing demand for carbohydrate-containing molecules for biological, pharmaceutical and medicinal studies has led to tremendous efforts to develop novel and facile methods for the synthesis of diverse glycosides. ${ }^{[3-7]}$ Recently, carbohydrate-containing macrocycles have also received great attention because of their application in bioorganic and supramolecular chemistry as inhibitors of carbohydrate-protein interactions or carbohydrate-RNA interactions in which the embedded carbohydrate structures are involved in binding to the receptor. ${ }^{[8]}$ They have also found application in host-guest chemistry, in the study of carbohydrate-carbohydrate interactions ${ }^{[9]}$ or in cyclodextrins or cyclodextrin mimetics, for instance, in glycophanes or their hybrids. ${ }^{[10]}$ The incorporation of carbohydrates into macrocycles facilitates the modification of their properties particularly by modification of the functional groups of the carbohydrate residue(s). ${ }^{[1,12]}$

[a] Fachbereich Chemie, Universität Konstanz, Fach 725, 78457 Konstanz, Germany Fax: $+49-7531-883135$ E-mail: richard.schmidt@uni-konstanz.de

[b] Department of Chemistry, Banaras Hindu University, Varanasi 221005, India

[c] Chemistry Department, Faculty of Science, King Abdulaziz University, Jeddah 21589, Saudi Arabia

Supporting information for this article is available on the WWW under http://dx.doi.org/10.1002/ejoc.201101815.
Although a large number of synthetic methods for glycoside bond formation are known, ${ }^{[5-7,13,14]}$ regio- and stereocontrol are not always achieved. To accomplish the desirable high selectivity in glycosidation reactions, intramolecular glycosylation has been studied as an attractive method. ${ }^{[15]}$ In this context it is worth mentioning that glycosyl transfer within the active site of an enzyme formally proceeds intramolecularly: the close proximity between glycosyl donor and acceptor in the active site of an enzyme is gained by specific binding between the enzyme and the substrate, thus leading to a structurally rigid array composed of large rings that enforce (regio- and/or) diastereoselectivity. ${ }^{[16.17]}$ To enforce a similar in vitro reaction course, various approaches to intramolecular glycoside bond formation have been investigated, ${ }^{[15-28]}$ which can be categorized into three major classes: (a) leaving group based, ${ }^{[18]}$ (b) functional substituent based ${ }^{[19]}$ and (c) rigid spacer based, as shown in Scheme 1. ${ }^{[20]}$
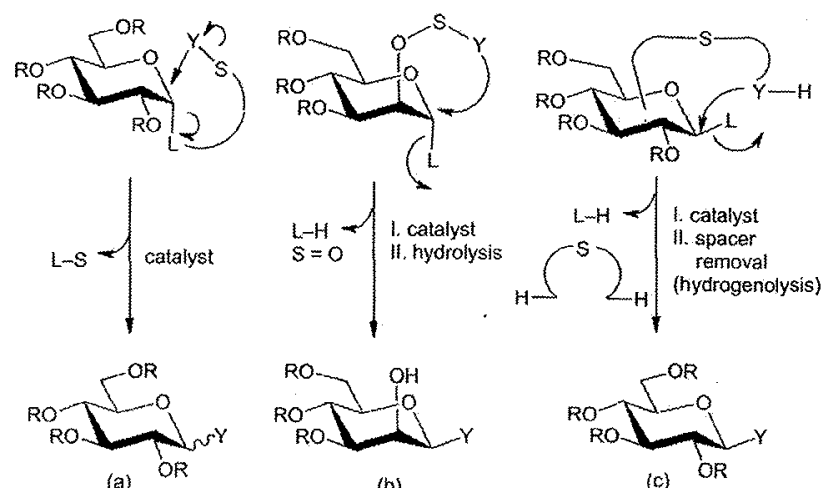

(b)

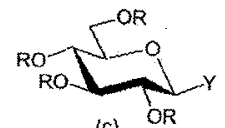

‘c\}

Scheme 1. Intramolecular glycoside bond formation. $\mathrm{L}=$ leaving group; $\mathrm{R}=$ protecting group; $\mathrm{S}=$ spacer; $\mathrm{Y}=$ acceptor. 
Generally, the functional-substituent-based approach (b), which generates five-membered cyclic transition states, resulted in good anomeric selectivity, yet this selectivity depends on the configuration of the 2-hydroxy group (thus, 2$\mathrm{OH}$ on the $\beta$-side gives the $\beta$-configuration and vice versa) and also on the spacer type. Larger spacer systems at the 2-OH or any other position of the donor often lead not only to lower anomeric selectivity but also to lower yields. An interesting alternative is spacer-mediated linkage of the glycosyl donor and acceptor by non-reacting centres (c), ${ }^{[20]}$ which lead, with the help of malonyl, ${ }^{[23]}$ succinyl, ${ }^{[24]}$ glutaryl ${ }^{[2.5]}$ or peptide spacers, ${ }^{[26]}$ to carbohydrate-containing macrocyclic systems. A combination of this approach with quite rigid spacers, for instance, $m$-xylylene, ${ }^{[16,20 a]}$ phthaloy ${ }^{[27]}$ or isophthaloyl, ${ }^{[28]}$ led in many cases to excellent results both in terms of yield and anomeric selectivity.

Herein we combine as rigid spacers $a$ - or $m$-xylylene residues with the ease of the triazole-forming click reaction to readily connect a glycosyl donor to an acceptor. The subsequent intramolecular glycosylation reaction gives rise to macrocycles containing the corresponding saccharides. The envisaged proximity of the triazolyl moiety to the anomeric centre will eventually influence the anomeric stereocontrol.

\section{Results and Discussion}

Thioglycoside 5, required as a glycosyl donor, was synthesised in good yield from D-glucose via ortho ester $\mathbf{2}$ in six steps (Scheme 2). The ortho ester ${ }^{[29 \mathrm{~d}-29 \mathrm{c}]}$ was prepared by a slightly modified procedure starting from glycosyl bromide 1; bromide 1 was heated in anhydrous acetonitrile at reflux in the presence of triethylamine, methanol and TBAI at $50^{\circ} \mathrm{C}$ for 45 min leading to an improved yield. The acetyl groups were removed with sodium methoxide and the resulting free hydroxy groups were benzylated to give ortho ester 2 in good yield; $\mathrm{HgBr}_{2}$-mediated ring-opening of the ortho ester with thiophenol is known to provide the thioglycoside in relatively low yield. ${ }^{[29 a]}$ However, when the ortho ester protection was removed by treatment with $p \mathrm{TsOH}$ and the compound 3 thus obtained was first $O$-acetyl-protected and then employed in the glycosylation of thiophenol with $\mathrm{BF}_{3} \cdot \mathrm{OEt}_{2}$ as promoter, compounds $\mathbf{5} \boldsymbol{\alpha}$ and $\mathbf{5} \boldsymbol{\beta}$ were obtained in good yields. The glycosylation with $\alpha$ isomer $4 \alpha$ proceeded faster than that of $\beta$-isomer $4 \beta$. Both diastereomers $\mathbf{5} \alpha$ and $\mathbf{5 0}$ were isolated in pure form. The $O$ acetyl groups of compounds $\mathbf{5} \boldsymbol{\alpha}$ and $\mathbf{5} \boldsymbol{\beta}$ were easily removed with $\mathrm{NaOMe}$ to give the desired thioglycosides $6 \alpha$ and $6 \beta$.
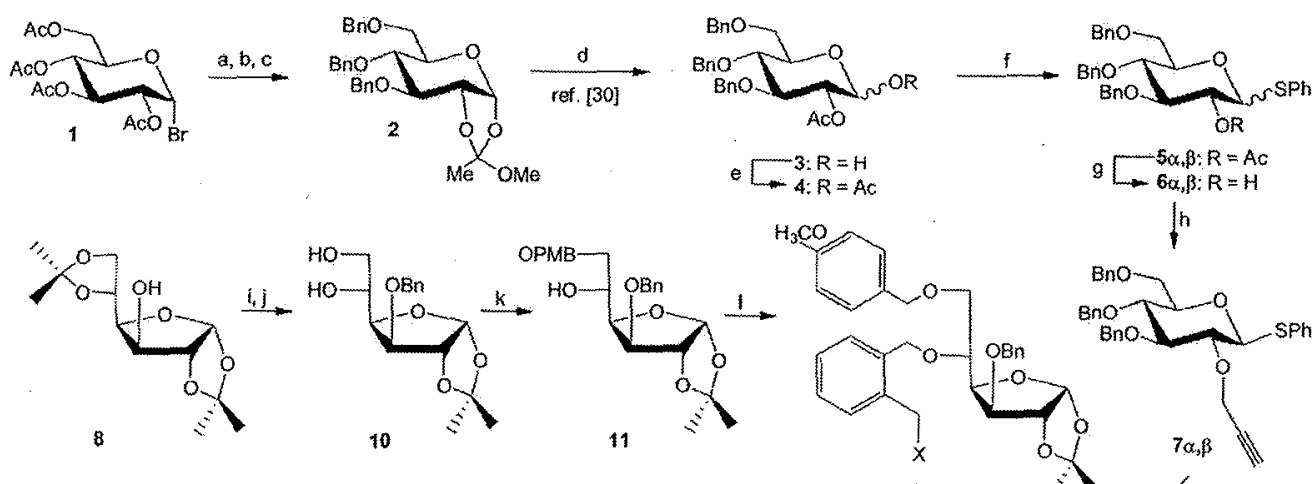

Ih
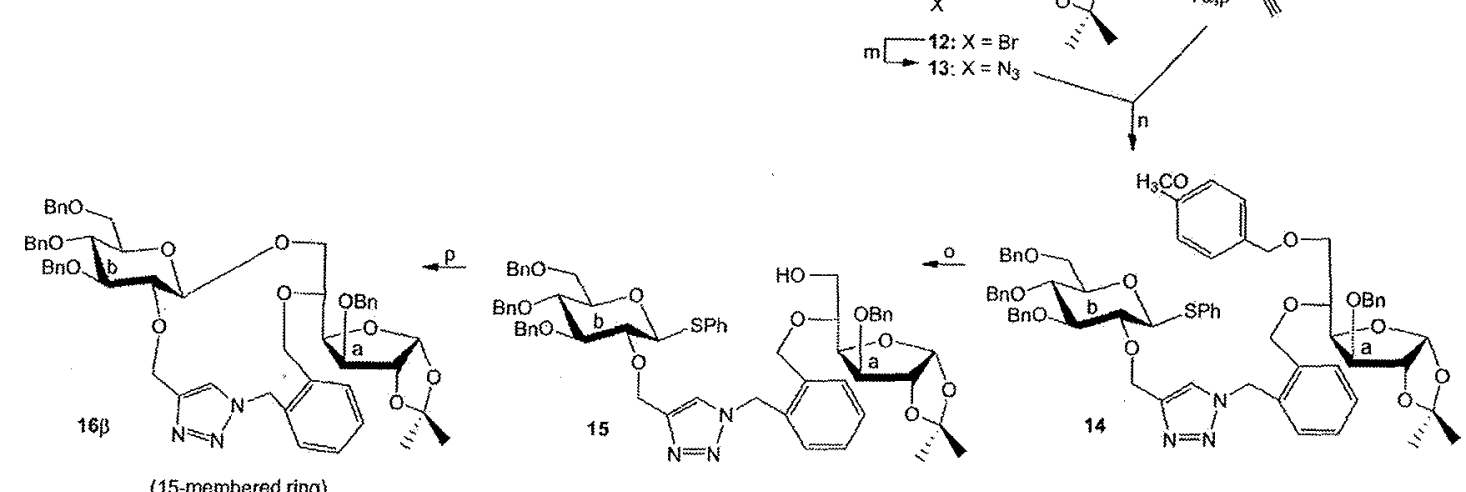

Scheme 2. Intramolecular glycosidic bond formation by click reaction with the formation of a 15 -membered ring. Reagents and conditions: (a) TBAI, NEt $, \mathrm{MeOH}, \mathrm{CH}_{3} \mathrm{CN}, 50{ }^{\circ} \mathrm{C}, 45 \mathrm{~min}, 95 \%$; (b) $\mathrm{NaOMe}, \mathrm{MeOH}, 3 \mathrm{~h}$, room temp., $98 \%$; (c) BnBr, DMF, TBAI, 90\%; (d) $p \mathrm{TsOH}$, acetone, $95 \%$; (e) $\mathrm{Ac}_{2} \mathrm{O}$, Pyr, 99\%; (f) $\mathrm{PhSH}, \mathrm{BF}_{3} \cdot \mathrm{OEt}_{2}, \mathrm{CH}_{2} \mathrm{Cl}_{2},-10{ }^{\circ} \mathrm{C}$ to room temp., $12 \mathrm{~h}, 70 \%$; (g) $\mathrm{NaOMe}, \mathrm{MeOH}, 99 \%$; (h) $\mathrm{HCCCH}_{2} \mathrm{Br}$, DMF, TBAI, $3 \mathrm{~h}$, room temp., 99\%; (i) BnBr, DMF, TBAl, room temp., $8 \mathrm{~h}, 99 \%$ ( $\rightarrow 9$ ); (j) $70 \% \mathrm{AcOH}$ (in $\mathrm{H}_{2} \mathrm{O}$ ), $80{ }^{\circ} \mathrm{C}$, $2 \mathrm{~h}, 92 \%$; (k) Bu $\mathrm{SnO}_{2}$, Tol, reflux, $5 \mathrm{~h}$, then PMBCl, NaH, TBAI, $90^{\circ} \mathrm{C}, 8 \mathrm{~h}, 90 \%$; (l) $\alpha, \alpha^{\prime}$-dibromo-o-xylene, $18-\mathrm{crown}^{-6}, \mathrm{NaH}, \mathrm{CH}{ }_{2} \mathrm{Cl}{ }_{2}$, $0^{\circ} \mathrm{C}$ to room temp., $14 \mathrm{~h}, 90 \% ;(\mathrm{m}) \mathrm{NaN}_{3}, \mathrm{DMF}, 50^{\circ} \mathrm{C}, 4 \mathrm{~h}, 99 \% ;$ (n) CuI, DIPEA, $\mathrm{CH}_{2} \mathrm{Cl}_{2}$, room temp., $12 \mathrm{~h}, 96 \% ;(\mathrm{o}) \mathrm{DDQ}, \mathrm{CH}_{2} \mathrm{Cl}$, $0{ }^{\circ} \mathrm{C}, 2 \mathrm{~h}, 82 \%$; (p) NIS, TMSOTf, $\mathrm{CH}_{2} \mathrm{Cl}_{2}, 0^{\circ} \mathrm{C}$ to room temp., $2 \mathrm{~h}, 58 \%$. 
Treatment with propargyl bromide in DMF using $\mathrm{NaH}$ (1.5 equiv.) resulted in the formation of $7 \alpha$ and $7 \beta$, respectively, in quantitative yields.

Sugar-based azide 13 was obtained from D-glucose in seven high-yielding steps. Treatment of diol 10, obtained in $92 \%$ yield from compound 8 , with dibutyltin oxide in toluene and then with $p$-methoxybenzyl chloride $(\mathrm{PMBCl})$ in the presence of tetrabutylammonium iodide resulted in selective 6-O-PMB protection by chelation with $\mathrm{Bu}_{2} \mathrm{SnO}$. Treatment of compound 11 with $\alpha, \alpha^{\prime}$-dibromo- $\alpha$-xylene in the presence of $\mathrm{NaH}$ as base and 18-crown-6 as supporting reagent led to $5-O$-linked derivative 12 in $90 \%$ yield. However, direct reaction of 11 with $\alpha, \alpha^{\prime}$-dibromo- $o$-xylene in the presence of $\mathrm{NaH}$ and in the absence of 18-crown-6 was not selective and provided three spots by TLC. Compound 12 on reaction with sodium azide at $50^{\circ} \mathrm{C}$ afforded the desired azide $\mathbf{1 3}$ in quantitative yield.

The $\mathrm{Cu}^{\mathrm{I}}$-catalysed Huisgen 1,3-dipolar cycloaddition (click reaction) of an azide and an alkyne has been increasingly used in the field of carbohydrate research for the chemical labelling of biomolecules ${ }^{[30 \mathrm{a}}$ as well as for the preparation of oligosaccharide analogues, ${ }^{[30 b]}$ glycol dendrimers, ${ }^{[30 c]}$ scaffolds ${ }^{[30 d]}$ and micro-arrays. ${ }^{[30 c]}$ Macrocyclic carbohydrates have recently been synthesized by click chemistry of azido and alkyne groups present in sialic acid containing oligosaccharides. ${ }^{[30 \text { [ }]}$ To explore the concept of intramolecular glycoside bond formation mediated by click reactions, $2-O$-propargyl- $\beta$-D-glucopyranoside (7/) was initially treated with glycosyl azide 13 to furnish triazole-containing derivative 14 in excellent yield. The PMB protecting group in compound 14 was removed by treatment with 2,3 dichloro-5,6-dicyanoquinone (DDQ) in $\mathrm{CH}_{2} \mathrm{Cl}_{2} / \mathrm{H}_{2} \mathrm{O}$. Activation of compound 15 with $\mathrm{N}$-iodosuccinimide (NIS, 2.0 equiv.) and trimethylsilyl trifluoromethanesulfonate (TMSOTf, 0.2 equiv.) in anhydrous $\mathrm{CH}_{2} \mathrm{Cl}_{2}$ at $0^{\circ} \mathrm{C}$ afforded the desired (1-6)-linked triazole-containing disaccharide 160 , as part of a 15 -membered macrocycle, as the only product (Scheme 2). As the yield of 160 was practically independent of the concentration of 15 in the $0.01-0.1$ molar range, oligomerization does not play a major role in the macrocyclization reaction. The $\beta$ configuration was assigned with the help of NMR spectroscopic data $\left({ }^{1} \mathrm{H}\right.$ : $1 \mathrm{~b}$ $\left.\mathrm{H}, J_{1,2}=7.6 \mathrm{~Hz} ;{ }^{13} \mathrm{C}: \mathrm{C}-1 \mathrm{~b}, \delta=101.75 \mathrm{ppm}\right)$. The yield of the glycosylation reaction with 15 and NIS/TMSOTf was concentration-dependent because 1.1 equiv. of NIS gave a lower yield of the product than 2 equiv. of NIS. As the reaction with $7 \alpha$ led to the same result, the diastereofacial control in the intramolecular glycosylation step was independent of the glycosyl donor configuration and even at room temperature the $\beta$ anomer was exclusively generated.

To further investigate intramolecular glycoside bond formation by the CuI-catalysed click reaction and the formation of 16-membered rings, compound $7 \beta$ was first treated with glycosyl azide 18 , obtained from 11 by a similar set of reactions with $\alpha, \alpha^{\prime}$-dibromo- $m$-xylene and then with sodium azide, to give triazole-containing carbohydrate 19 (Scheme 3). The removal of PMB from 19 by treatment with DDQ in $\mathrm{CH}_{2} \mathrm{Cl}_{2} / \mathrm{H}_{2} \mathrm{O}$ followed by final intramolecular aglycon delivery by activation of compound $\mathbf{2 0}$ with NIS (2.0 equiv.) and TMSOTf ( 0.2 equiv.) in anhydrous $\mathrm{CH}_{2} \mathrm{Cl}_{2}$ at $0{ }^{\circ} \mathrm{C}$ afforded the desired (1-6)-linked triazole-containing disaccharide compounds 210 and $21 \beta$ that could be separated. The $\beta / \alpha$. selectivity dropped to $3: 1$ for the formation of the 16-membered macrocyclic rings.

Then we turned our attention to intramolecular glycosylation reactions of acceptors with secondary hydroxy groups. The first studies were performed with 6-O-linked glucofuranoses (Scheme 4). To this end, readily available glucofuranose 10, after regioselective 6-O-trityl protection $(\rightarrow 22)$ followed by 5-O-PMB protection $(\rightarrow 23)$ and finally treatment with $p \mathrm{TsOH}$, afforded 6-O-unprotected glucofuranose 24 in an overall yield of 88\%. 18-Crown-6-supported reaction of 24 with $a, \alpha^{\prime}$-dibromo- $o$ - or $-m$-xylene $(\rightarrow 25$ and 30) followed by treatment with sodium azide afforded 6-O.

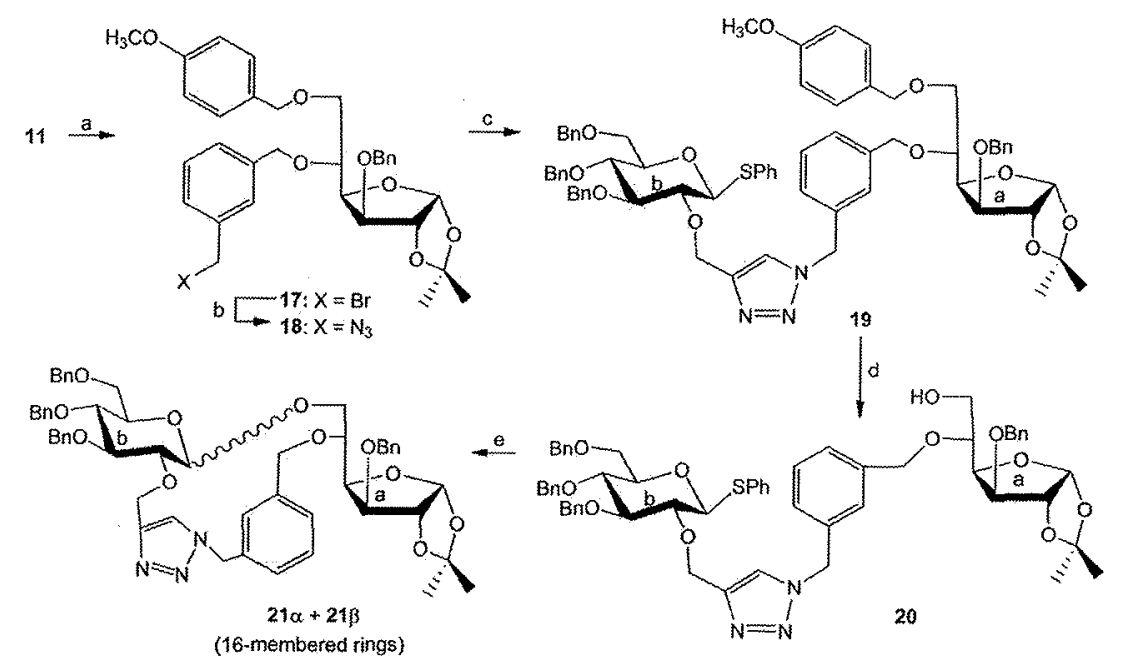

Scheme 3. Intramolecular glycosidic bond formation by click reaction in the formation of 16-membered rings. Reagents and conditions: (a) $\alpha, \alpha^{\prime}$-dibromo $m$-xylene, 18 -crown-6, $\mathrm{NaH}, \mathrm{CH}_{2} \mathrm{Cl}_{2}, 0^{\circ} \mathrm{C}$ to room temp., $14 \mathrm{~h}, 96 \% ;$ (b) $\mathrm{NaN}, \mathrm{DMF}, 50{ }^{\circ} \mathrm{C}, 4 \mathrm{~h}, 99 \% ;$ (c) $7 \mathrm{~B}, \mathrm{CuI}$, DIPEA, $\mathrm{CH}_{2} \mathrm{Cl}_{2}$, room temp., $10 \mathrm{~h}, 96 \%$; (d) DDQ, $\mathrm{CH}_{2} \mathrm{Cl}_{2}, \mathrm{H}_{2} \mathrm{O}, 0^{\circ} \mathrm{C}, 2 \mathrm{~h}, 80 \% ;$ (e) NIS, TMSOTf, CH${ }_{2} \mathrm{Cl}, 0^{\circ} \mathrm{C}, 2 \mathrm{~h}, 65 \%, 6 / \alpha=3: 1$. 


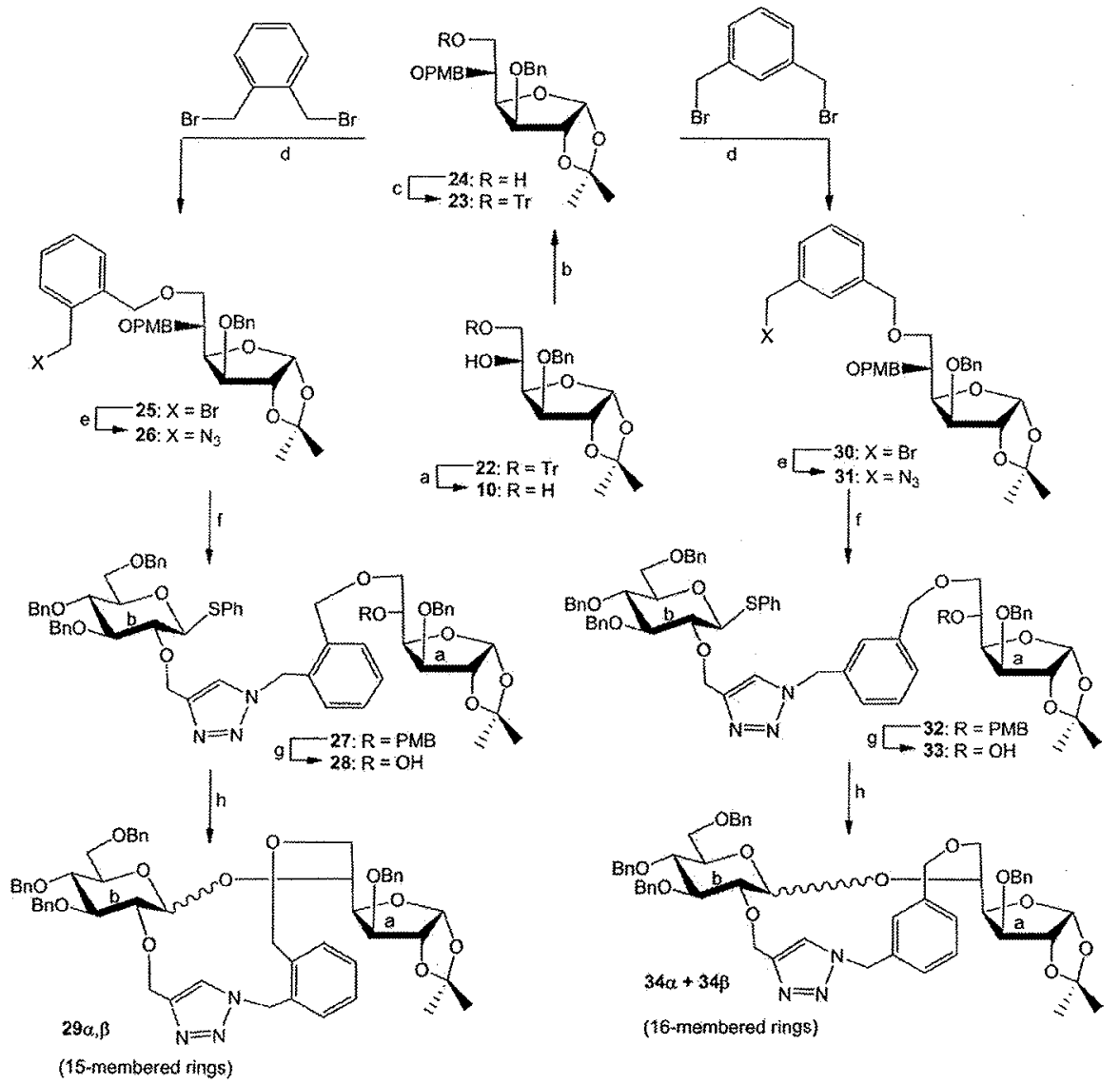

Scheme 4. Intramolecular glycosidic bond formation through click reactions to form 15- or 16-membered rings. Reagents and conditions: (a) $\mathrm{CPh}_{3} \mathrm{Cl}$, Pyr, room temp., $10 \mathrm{~h}, 95 \%$; (b) $\mathrm{PMBBr}, \mathrm{DMF}$, TBAI, room temp., $10 \mathrm{~h}, 97 \%$; (c) PTSA, $\mathrm{CH}_{2} \mathrm{Cl}_{2}, \mathrm{MeOH}^{\circ}$, room temp., overnight, $95 \%$; (d) 18-crown-6, $\mathrm{NaH}, \mathrm{CH}_{2} \mathrm{Cl}_{2}, 0^{\circ} \mathrm{C}$ to room temp., $14 \mathrm{~h}, 85$ (25) and $90 \%(30)$; (e) $\mathrm{NaN}_{3}, \mathrm{DMF}, 50^{\circ} \mathrm{C}, 4 \mathrm{~h}, 99(26)$ and $98 \%$ (31); (f) 73, $\mathrm{CH}_{2} \mathrm{Cl}_{2}$, CuI, DIPEA, room temp., $10 \mathrm{~h}, 95$ (27) and $98 \%$ (32); (g) DDQ, $\mathrm{CH}_{2} \mathrm{Cl}_{2}, \mathrm{H}_{2} \mathrm{O}, 2 \mathrm{~h}, 88$ (28) and $85 \%$ (33); (h) NIS, TMSOTf, $2 \mathrm{~h}, 80 \%, \alpha / \beta=3: 2$ (29) and $50 \%, \alpha / \beta=2: 1(34)$.

linked azides $\mathbf{2 6}$ and $\mathbf{3 1}$, respectively, in good yields. The Cul-catalysed click reactions of compound $7 p$ with azides 26 and 31 resulted in nearly quantitative conversion to sugar-containing triazoles 27 and 32 , respectively.

DDQ-mediated cleavage of the PMB group in 27 furnished the required $5 \mathrm{a}-\mathrm{O}$-unprotected intermediate $\mathbf{2 8}$, which, upon treatment with NIS (2.0 equiv.) and TMSOTf (0.2 equiv.) in $\mathrm{CH}_{2} \mathrm{Cl}_{2}$ at $0^{\circ} \mathrm{C}$, afforded the desired intramolecular glycosylation products $29 \alpha, \beta$ through the formation of a 15-membered macrocycle in $80 \%$ yield as a $3: 2 \alpha / \beta$ mixture. Separation of the anomers was difficult as both compounds had the same $R_{\mathrm{f}}$ value $\left(R_{\mathrm{f}}=0.35\right.$, EtOAc/toluene $=3: 7$ ). Similar transformation of 32 into 5 a-O-unprotected intermediate $\mathbf{3 3}$ and then intramolecular glycosylation with NIS/TMSOTf as activating system led to the 16membered macrocycles $34 \alpha, \beta$ (that could not be separated) in good yield with an $\alpha / \beta$ ratio of $2: 1$.

As the models 28 and $\mathbf{3 3}$ for intramolecular glycosylation studies possess high conformational flexibility, not only in parts of the linker, but also in the acceptor moiety, a related system with a conformationally more restricted acceptor moiety was investigated. To this end, readily available $O$ - isopropylidene-protected glucofuranose 8 was 3-O-alkylated with $\alpha, \alpha^{\prime}$-dibromo-o-xylene to afford bromomethylbenzyl derivative 35 , which on reaction with sodium azide in DMF afforded the corresponding azide 36 (Scheme 5). Selective 5,6-O-de-isopropylidenation with aqueous acetic acid $(\rightarrow 37)$ and then regioselective 6-O-benzoylation with benzoyl chloride in $\mathrm{CH}_{2} \mathrm{Cl}_{2}$ /pyridine at $-30^{\circ} \mathrm{C}$ furnished $5-$ $O$-unprotected intermediate 38 , which gave on reaction with 2-O-propargyl derivative $7 \beta$ under 1,3-dipolar cycloaddition (click) reaction conditions donor-acceptor-linked intermediate 39 in excellent yield. Glycosylation under the standard conditions gave only the $\alpha(1-5)$-linked disaccharide $40 \alpha$ as part of a 16-membered macrocycle in low yield. Therefore it was not surprising that glycosylation studies with $O$-protected 41 , readily obtained by the click reaction of $7 \beta$ and 36, did not lead to glycoside bond formation with concomitant loss of the 5a,6a- $O$-isopropylidene group. The reaction centres do not seem to be well adjusted for intramolecular glycoside bond formation.

After studying the 1,2-O-isopropylideneglucofuranose derivatives as acceptors we investigated pyranoside acceptors, which are generally conformationally more rigid. 


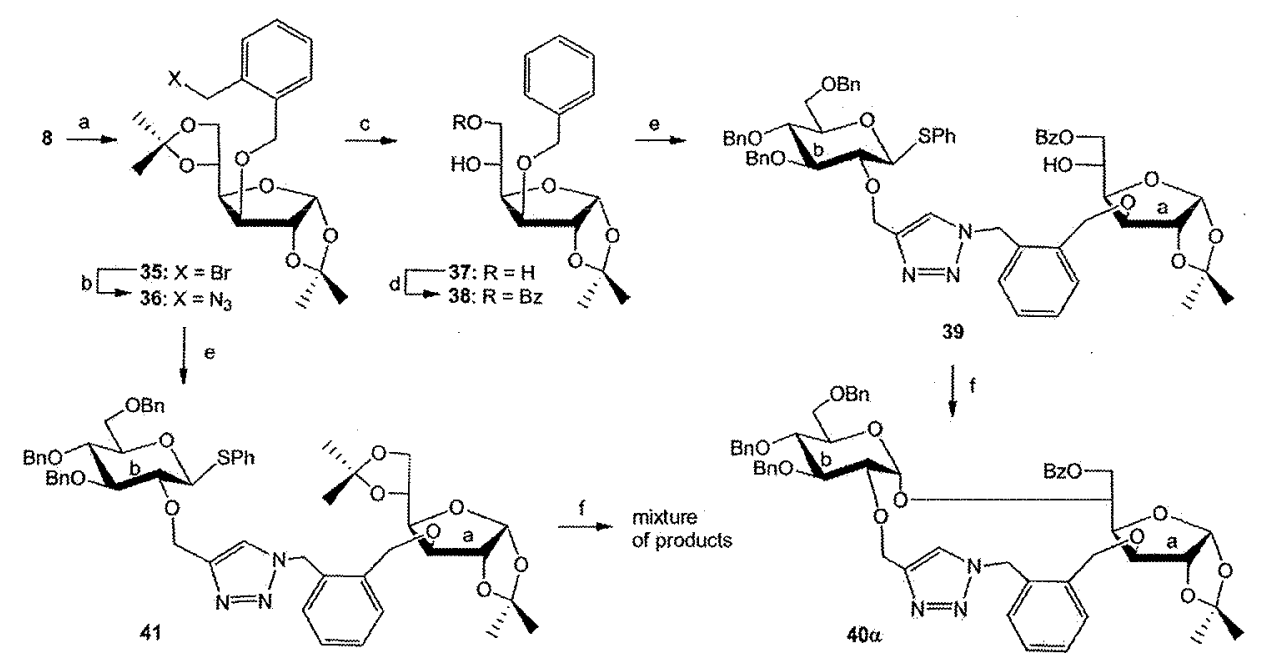

Scheme 5. Intramolecular glycosidic bond formation by click reaction to form a 16-membered ring. Reagents and conditions: (a) 18 crown-6, $\mathrm{NaH}, \mathrm{CH}_{2} \mathrm{Cl}_{2}, 0^{\circ} \mathrm{C}$ to room temp., $14 \mathrm{~h}, 90 \%$; (b) $\mathrm{NaN}_{3}, \mathrm{DMF}, 50{ }^{\circ} \mathrm{C}, 4 \mathrm{~h}, 98 \%$; (c) $70 \% \mathrm{AcOH}$, room temp., $12 \mathrm{~h}, 94 \%$;

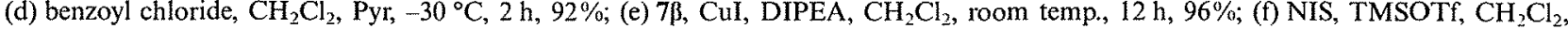
$3 \mathrm{~h}, 20 \%$.

They are also typical of mammalian systems. To this end, known methyl 2,3-di- $O$-benzylglucopyranoside 45 was regioselectively protected with dibutyltin oxide and 4-PMBCl to afford 6-O-PMB-protected derivative 46 (Scheme 6). Re- action with $\alpha, \alpha^{\prime}$-dibromo-o- and - $m$-xylene in the presence of 18-crown-6 and $\mathrm{NaH}$ as base furnished 4-O-alkylation products 47 and 52 , respectively, which were transformed into azides 48 and 53 . Their click reaction with 2-O-prop-

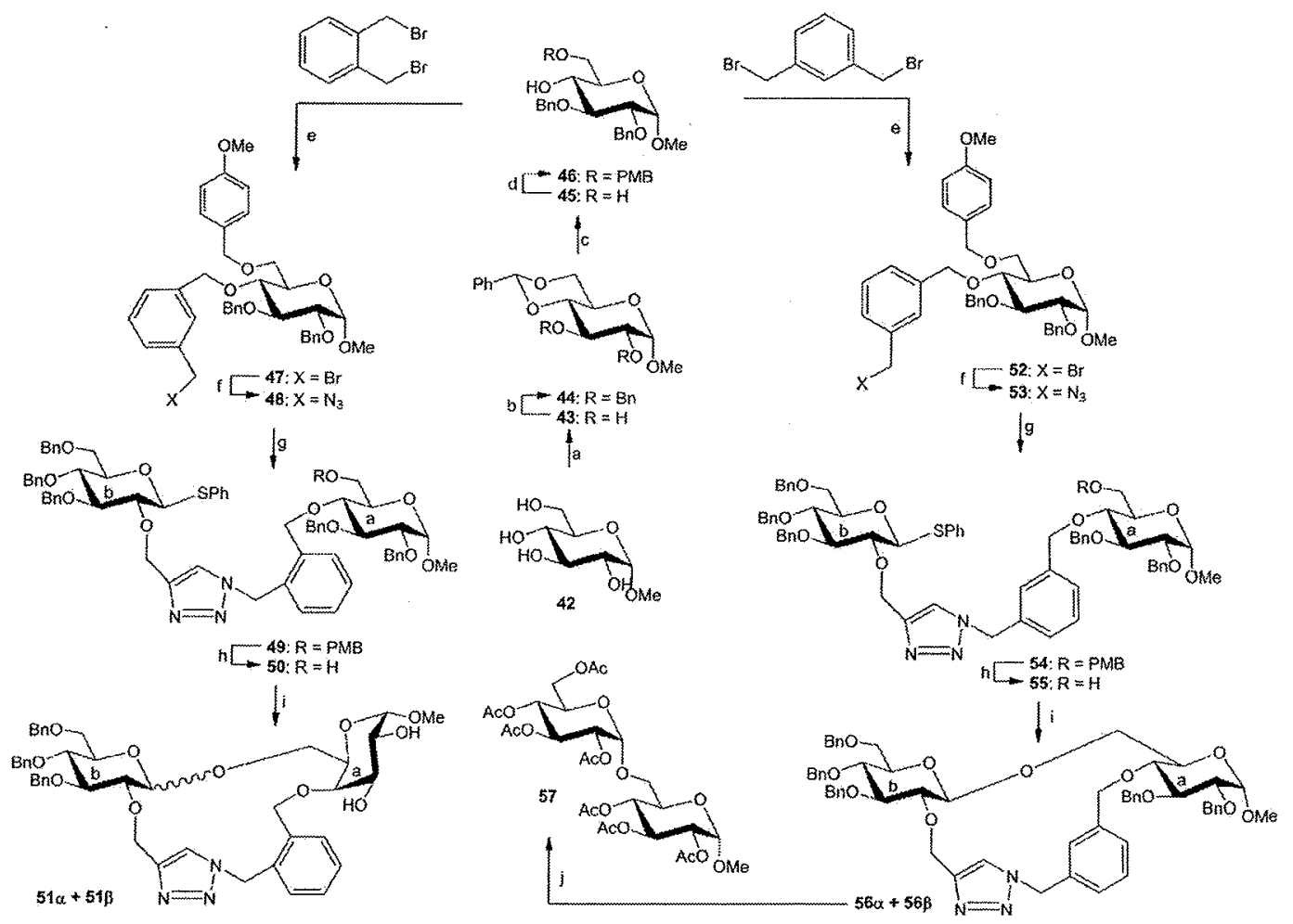

Scheme 6. Intramolecular glycosidic bond formation by click reaction to form 16- and 17-membered rings. Reagents and conditions: (a) PhCH(OMe) $)_{2}$, DMF, PTSA, $1 \mathrm{~h}, 50^{\circ} \mathrm{C}, 95 \%(\rightarrow 43)$; (b) $\mathrm{BnBr}$, DMF, TBAI, room temp., $10 \mathrm{~h}, 95 \%$; (c) TFA, $\mathrm{CH}_{2} \mathrm{Cl}_{2}, \mathrm{H}_{2} \mathrm{O}, 0^{\circ} \mathrm{C}$, $2 \mathrm{~h}, 96 \%(\rightarrow 45)$; (d) $\mathrm{Bu}_{2} \mathrm{SnO}$, Tol, reflux, $5 \mathrm{~h}, \mathrm{PMBCl}$, TBAI, $90{ }^{\circ} \mathrm{C}, 8 \mathrm{~h}, 94 \%$; (e) 18-crown-6, $\mathrm{NaH}, \mathrm{CH}_{2} \mathrm{Cl}_{2}, 0^{\circ} \mathrm{C}$ to room temp., $14 \mathrm{~h}$, 95 (47) and $90 \%(52) ;(f) \mathrm{NaN}_{3}, \mathrm{DMF}, 50^{\circ} \mathrm{C}, 4 \mathrm{~h}, 98 \%$; (g) 7ß, CuI, DIPEA, $\mathrm{CH}_{2} \mathrm{Cl}_{2}$, room temp., $14 \mathrm{~h}, 96(49)$ and 92\% (54); (h) DDQ, $\mathrm{CH}_{2} \mathrm{Cl}_{2}, \mathrm{H}_{2} \mathrm{O}, 2 \mathrm{~h}, 90(\mathbf{5 0})$ and $86 \%(55)$; (i) NIS, TMSOTf, $2 \mathrm{~h}, 95 \%, \alpha / \beta=1: 2(\mathbf{5 1})$ and $80 \%, \alpha / \beta=3: 2(\mathbf{5 6}) ;(\mathrm{j}) \mathrm{H}, \mathrm{Pd} / \mathrm{C}$, methanol, $\mathrm{HCl}, 2 \mathrm{~d}$ then $\mathrm{Ac}_{2} \mathrm{O}, \mathrm{Py}, 0^{\circ} \mathrm{C}, 10 \%$. 
argyl-protected donor 70 afforded the donor-acceptorlinked compounds 49 and 54, respectively. DDQ-mediated removal of the PMB group ( $\rightarrow \mathbf{5 0}$ and $\mathbf{5 5}$ ) followed by glycosylation under standard conditions afforded the (1-6)linked intramolecular glycosylation products $51 \alpha, \beta$ and $56 a / \beta$, respectively, in high yields but with modest anomeric preferences $(51: \alpha / \beta=1: 2,56: \alpha / \beta=3: 2)$. This and previous results show that the formation of anomers is only marginally influenced, if at all, by anchimeric assistance of the triazolyl moiety, although the N-3 atom could bind to the anomeric carbon to generate a six-membered heterocycle.

Attempts to remove all the $O$-benzyl groups and the linker were carried out with macrocycle $56 \alpha$ (Scheme 6). Hydrogenolysis with palladium on carbon as catalyst afforded after $O$-acetylation the known methyl isomaltoside 57, although in low yield. Hence, conditions for the cleavage of the triazolylmethyl moiety have to be further optimized. [31]

The transformation of glucopyranoside 45 into a 4-Ounprotected acceptor was performed to study the formation of an intramolecular (1-4)-linkage between two glucopyranose residues. To this end, 4,6-O-unprotected glucose derivative 45 was tritylated with trityl (Trt) chloride in pyridine to afford regioselectively the 6-O-trityl derivative. The PMB group was then introduced at 4-O under standard conditions to furnish the fully $O$-protected intermediate 59
(Scheme 7). $p$ TsOH-catalysed detritylation led to 6-O-unprotected compound $\mathbf{6 0}$ in high overall yield, thus providing a suitable compound for the envisaged studies. Alkylation with $0, \alpha^{\prime}$-dibromo- $o$ - and - $m$-xylene afforded compounds 61 and 66 , respectively. Azide introduction $(\rightarrow 62$ and 67$)$, click reaction with glucopyranosyl donor $7 \beta$ ( $\rightarrow 63$ and 68 ) and then DDQ-mediated PMB cleavage furnished the desired precursors 64 and 69, respectively, for the intramolecular glycosylation studies. Treatment with NIS/TMSOTf as promoter afforded the desired 16- and 17-membered macrocycles $65 \alpha, \beta$ and $70 \alpha$ and $70 \beta$, respectively, in high yields. Mixtures of $\alpha$ and $\beta$ anomers were obtained in both cases $(65: 90 \%, \alpha / \beta=3: 1 ; 70: 82 \%, \alpha / \beta=1: 2)$. Notably, and in contrast to the formation of 51 and 56 , the 16-membered macrocycle was generated mainly with an $\alpha$-glycosidic linkage whereas the 17 -membered macrocycle was generated with a preference for the $\beta$ product.

From this result it was concluded that a reduction in ring size, for example, in the transformation of 64 into 65 , will eventually lead to a single anomer, that is, the $\alpha$ anomer. The corresponding 15-membered macrocycle can be easily synthesized by attaching the $o$-xylyl-linker to the 3-hydroxy group of the acceptor. By this approach the formal $(5,4)$-Lthreo attachment to the acceptor in intermediate 64 (Scheme 7) ${ }^{[15]}$ is inverted, as can be seen by comparison with the corresponding target molecule 76 (Scheme 8).

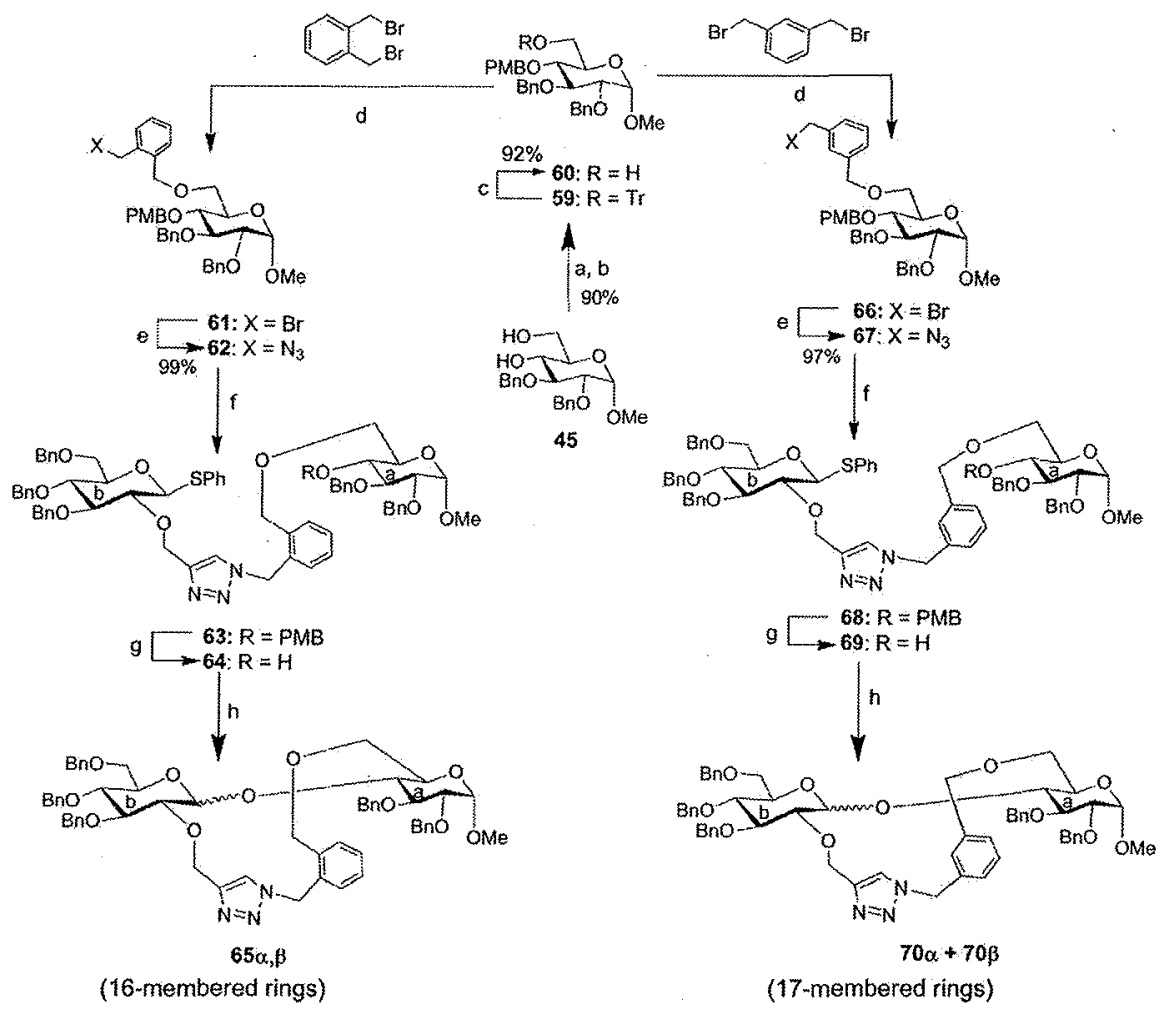

Scheme 7. Intramolecular glycosidic bond formation by click reaction to form 16- and 17-membered rings. Reagents and conditions: (a) TrCl, Pyr, $12 \mathrm{~h}, 0^{\circ} \mathrm{C}$ to room temp., 94\% ( $\rightarrow$ 58); (b) PMBCl, NaH, DMF, room temp., $10 \mathrm{~h}, 95 \%$; (c) PTSA, $\mathrm{MeOH} \mathrm{CH}_{2} \mathrm{Cl}_{2}, 0^{\circ} \mathrm{C}$, $92 \%, 2 \mathrm{~h}$; (d) 18-crown-6, $\mathrm{NaH}, \mathrm{CH}_{2} \mathrm{Cl}_{2}, 0^{\circ} \mathrm{C}$ to room temp., $14 \mathrm{~h}, 90$ (61) and $88 \%$ (66); (e) $\mathrm{NaN}_{3}, \mathrm{DMF}, 50{ }^{\circ} \mathrm{C}, 4 \mathrm{~h}, 99(62)$ and $97 \%$ (67); (f) 7p, CuI, DIPEA, $\mathrm{CH}_{2} \mathrm{Cl}_{2}, 14 \mathrm{~h}, 95$ (63) and 96\% (68); (g) DDQ, $\mathrm{CH}_{2} \mathrm{Cl}_{2}, \mathrm{H}_{2} \mathrm{O}, 0^{\circ} \mathrm{C}, 2 \mathrm{~h}, 87$ (64) and 90\% (69); (h) NIS, TMSOTf, $\mathrm{CH}_{2} \mathrm{Cl}_{2}, 2 \mathrm{~h}, 90 \%, \alpha / \beta=3: 1(65)$ and $82 \%, \alpha / \beta=1: 2(70)$. 


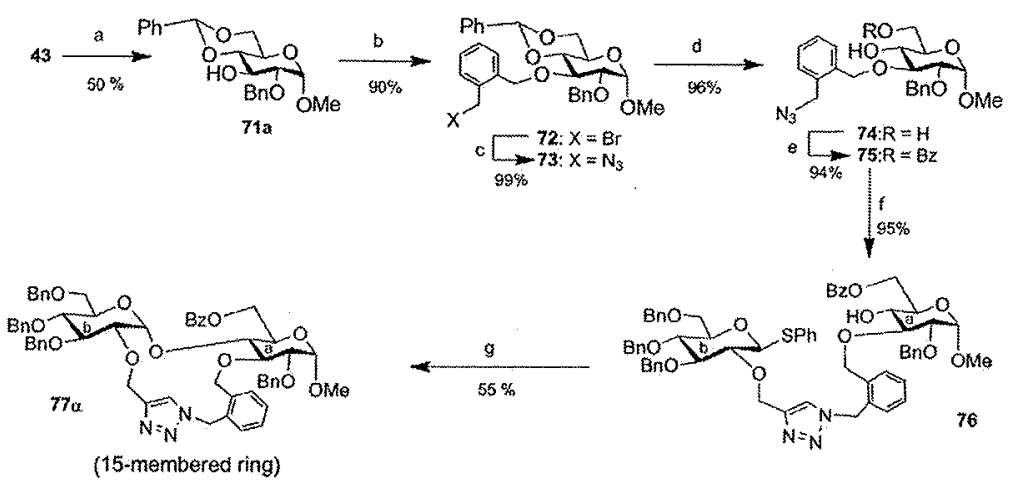

Scheme 8 . Intramolecular glycosidic bond formation by click reaction to form a 15 -membered ring. Reagents and conditions: (a) $\mathrm{BnBr}$, $\mathrm{CH}_{2} \mathrm{Cl}_{2}, \mathrm{NaOH}, \mathrm{Bu}_{4} \mathrm{NHSO}_{4}, 60^{\circ} \mathrm{C}, 48 \mathrm{~h}, 50$ (71a), 20 (71b) and $10 \%$ (mixture of dibenzyl-protected compounds); (b) $\alpha, \alpha^{\prime}$-dibromo- $o$ xylene, Pyr $/ \mathrm{CH}_{2} \mathrm{Cl}_{2}, 18$-crown-6, $0{ }^{\circ} \mathrm{C}$, room temp., $18 \mathrm{~h}, 90 \%$; (c) $\mathrm{NaN}_{3}, \mathrm{DMF}, 50{ }^{\circ} \mathrm{C}, 4 \mathrm{~h}, 99 \%$; (d) $70 \% \mathrm{AcOH} / \mathrm{H}_{2} \mathrm{O}, 70{ }^{\circ} \mathrm{C}, 3 \mathrm{~h}, 96 \%$; (e) $\mathrm{BzCl}, \mathrm{CH}_{2} \mathrm{Cl}_{2},-40^{\circ} \mathrm{C}, 1 \mathrm{~h}, 94 \%$; (f) 7 , CuI, DIPEA, $\mathrm{CH}_{2} \mathrm{Cl}_{2}, 14 \mathrm{~h}, 96 \%$; (g) NIS, TMSOTf, $\mathrm{CH}_{2} \mathrm{Cl}_{2}, 55 \%$.

However, from molecular models it can be deduced that this stereochemical change should not negatively influence the result of glycosylation. Thus, 2,3-O-unprotected glucopyranoside $43^{[32]}$ was monobenzylated under phase-transfer conditions $^{[3]}$ to furnish mainly the $2-O$-benzyl derivative 71a (together with some 3-O-benzyl derivative 71b). Subsequent reaction with $\alpha, \alpha^{\prime}$-dibromo- $o$-xylene afforded intermediate 72, which was transformed into azide 73. Acid-catalysed debenzylidenation $(\rightarrow 74)$ and then benzoylation with benzoyl chloride in pyridine at $-40^{\circ} \mathrm{C}$ regioselectively furnished 6-O-benzoyl derivative 75 . Click reaction of azide 75 with donor $7 \beta$ led to the required triazole-containing disaccharide 76 as precursor for the intramolecular glycosylation. NIS/TMSOTf-promoted activation of 76 exclusively afforded, as expected, the o(1-4)-linkage of the 15-membered macrocycle $77 \boldsymbol{a}$, as indicated by ${ }^{13} \mathrm{C}$ NMR spectroscopy (C-1a: $\delta=97.72 \mathrm{ppm}$; C-1b: $\delta=97.73 \mathrm{ppm}$ ).

\section{Conclusions}

The 1,4-substituted triazole-forming click reactions between 2-O-propargyl-substituted glucopyranosyl donors and $O$-(2- or 3-azidomethylbenzyl)-protected glycosyl acceptors has provided a convenient access to donor-acceptor-ligated intermediates with a quite rigid spacer. Glycosylation reactions led to the desired disaccharides as part of macrocycles generally in good-to-excellent yields, thus confirming the efficiency of this approach to intramolecular glycoside bond formation. Modest-to-excellent anomeric stereocontrol was observed, hence, further studies with different spacer linkage positions, different ring size and possibly different leaving groups or reaction conditions are required to optimize the anomeric stereoselectivity. Note that anchimeric assistance by the neighbouring triazolyl moiety was negligible in the anomeric stereocontrol.

\section{Experimental Section}

General: Solvents were purified by standard procedures. Yields refer to chromatographically pure material. Anomeric selectivities are based on isolated material or on 'H NMR spectroscopic data. Reactions were monitored by TLC carried out on Merck silica gel $(0.2 \mathrm{~mm}, 60 \mathrm{~F}-254)$ plastic plates. Compounds were first visualized under UV light and then by using visualizing agent, a solution of $\left(\mathrm{NH}_{4}\right)_{6} \mathrm{Mo}_{3} \mathrm{O}_{24} \cdot 4 \mathrm{H}_{2} \mathrm{O}(20 \mathrm{~g})$ and $\mathrm{Ce}\left(\mathrm{SO}_{4}\right)_{2}(0.4 \mathrm{~g})$ in sulfuric acid $(10 \%, 400 \mathrm{~mL})$, and heating to $120^{\circ} \mathrm{C}$ and/or an ethanolic sulfuric acid solution and heat as developing agents. Flash chromatography was performed on $\mathrm{MN}$ silica gel $60(230-400 \mathrm{mesh})$ at a pressure of 0.2 bar. NMR spectra, including ${ }^{1} \mathrm{H}$ and ${ }^{\prime} \mathrm{C}$ NMR, DEPT, COSY, HSQC and HMBC spectra, were acquired with a Bruker $400 \mathrm{MHz}$ NMR spectrometer at $300 \mathrm{~K}$; tetramethylsilane (TMS) and the resonance of undeuteriated solvent were used as internal standards $\left(\mathrm{CDCl}_{3}: \delta=7.25 \mathrm{ppm}\right)$. The multiplicities are indicated as follows: $\mathrm{m}=$ multiplet, $\mathrm{s}=$ singlet, $\mathrm{d}=$ doublet, $\mathrm{dd}=$ double of doublets, $\mathrm{t}$ $=$ triplet, $\mathrm{dt}=$ doublet of triplets, $\mathrm{br} . \mathrm{s}=$ broad singlet. Mass spectra were recorded with a Bruker ESI-MS mass spectrometer. HRMS were obtained with a Fourier-transform mass spectrometer. Optical rotations were measured at $20^{\circ} \mathrm{C}$ with a Büchi Polar-Monitor ( $1 \mathrm{dm}$ cell) using the sodium $\mathrm{D}$ line.

Synthetic methods for all donors, acceptors and intermediates required to investigate the intramolecular glycosylation reactions are given in the Supporting Information.

General Procedure A - Synthesis of Glycosyl Azides: 18-Crown-6 (480 $\mathrm{mg}, 1.82 \mathrm{mmol}$ ) and sodium hydride $(300 \mathrm{mg}$ ) were added to a solution of free alcohol $(5.69 \mathrm{mmol})$ in anhydrous dichloromethane $(30 \mathrm{~mL})$ and then the mixture was stirred for $10 \mathrm{~min}$ at $-10^{\circ} \mathrm{C}$ under an inert atmosphere, $\alpha, \alpha^{\prime}$-Dibromo- $o$ - or $-m$-xylene $(11.39 \mathrm{mmol})$ in dichloromethane $(15 \mathrm{~mL})$ was added to the reaction mixture at room temp. and stirring was continued overnight. Progress of the reaction was monitored by TLC and the reaction was continued until the starting material had been consumed. The solution was then filtered through Celite (carefully) and concentrated in vacuo. Chromatography (toluene/ethyl acetate) of the residue afforded the desired compound as a colourless oil. The yields refer to the isolated compounds and varied from $80-90 \%$ (excess $a, \alpha^{\prime}$-dibromo- $\alpha$ or $-m$-xylene was recovered and reused). The pure product thus obtained was dissolved in anhydrous DMF (10 $15 \mathrm{~mL}$ ) and excess of $\mathrm{NaN}_{3}$ (4 equiv.) was added. The reaction mixture was stirred at $50{ }^{\circ} \mathrm{C}$ for $3-4 \mathrm{~h}$. The solvent was then evaporated under reduced pressure and the crude mass was filtered. Flash chromatography revealed an almost quantitative yield of the glycosyl azide as a colourless oil. 
General Procedure B - Synthesis of Glycosyl Triazole by CopperCatalysed Click Reaction: Equimolar amounts of the glycosyl alkyne $(2.79 \mathrm{mmol})$ and glycosyl azide $(2.79 \mathrm{mmol})$ were dissolved in anhydrous $\mathrm{CH}_{2} \mathrm{Cl}_{2}(30 \mathrm{~mL})$ and diisopropylethylamine $(3.1 \mathrm{mmol})$ was added. The solution was mixed for $10 \mathrm{~min}$. Copper(I) iodide powder $(0.55 \mathrm{mmol})$ was then added to the reaction mixture at $0^{\circ} \mathrm{C}$ and the solution stirred at room temp. for 9-12 h. The progress of the reaction was monitored by TLC using $30 \%$ EtOAc/toluene as developing solvent and $5 \% \mathrm{H}_{2} \mathrm{SO}_{4}$ (in ethanol) solution for sugar staining. The mixture was filtered through Celite and concentrated in vacuo. The crude product thus obtained was subjected to flash column chromatography using silica. The desired triazole was obtained as a colourless oil in almost quantitative yield.

General Procedure C - PMB Group Removal: DDQ (1.01 mmol) was added slowly to a stirring solution of the triazole $(1.0 \mathrm{mmol})$ in a mixture of $\mathrm{CH}_{2} \mathrm{Cl}_{2}(27 \mathrm{~mL})$ and distilled water $(3.0 \mathrm{~mL})$ at $0{ }^{\circ} \mathrm{C}$ and the resulting reaction mixture was stirred at the same temperature for $2 \mathrm{~h}$. The reaction mixture was filtered, extracted with $\mathrm{CH}_{2} \mathrm{Cl}_{2}$, washed with $\mathrm{H}_{2} \mathrm{O}(10 \mathrm{~mL})$, the solvent evaporated under reduced pressure, and the residue purified by column chromatography using $40 \%$ EtOAc/toluene as eluent to give the desired free alcohol.

General Procedure D - Intramolecular Glycosylation of TriazoleContaining Carbohydrates: Trimethylsilyl trifluoromethanesulfonate ( 0.3 equiv.) was added through a syringe under argon to a stirring solution of triazole-containing carbohydrate $(1.0 \mathrm{mmol})$ and $\mathrm{N}$-iodosuccinimide $(2.0 \mathrm{mmol})$ in anhydrous dichloromethane $(20 \mathrm{~mL})$ at $-10^{\circ} \mathrm{C}$ under an inert atmosphere. The reaction was stirred for $1-2 \mathrm{~h}$ at room temp. if not indicated otherwise. The solution was neutralized with triethylamine at $0^{\circ} \mathrm{C}$, sodium dithionite was added and then stirring was continued until the solution became colourless. The solid was filtered off and the solution was extracted with $\mathrm{CH}_{2} \mathrm{Cl}_{2}(2 \times 75 \mathrm{~mL})$, washed with $\mathrm{H}_{2} \mathrm{O}(10 \mathrm{~mL})$, dried with anhydrous $\mathrm{Na}_{2} \mathrm{SO}_{4}$ and the solvent removed under vacuo. The residue thus obtained was subjected to flash chromatography ( $20 \%$ EtOAc/toluene) to give the sugar-based macrocycle as a colourless oil. The yields refer to the isolated pure products obtained by column chromatography and the selectivities were determined by NMR analysis of the crude reaction mixtures.

Compound 16ק: TMSOTf ( $15 \mu \mathrm{L}, 0.07 \mathrm{mmol}$ ) was added through a syringe under argon to a stirring solution of $15(314 \mathrm{mg}$, $0.303 \mathrm{mmol}$ ) and $N$-iodosuccinimide (136 $\mathrm{mg}, 0.606 \mathrm{mmol})$ in dry dichloromethane $(20 \mathrm{~mL})$ at $-10^{\circ} \mathrm{C}$ under an inert atmosphere. The reaction was stirred for $90 \mathrm{~min}$ at room temp. The solution was neutralized with triethylamine at $0^{\circ} \mathrm{C}$, sodium dithionite was added, and then stirring was continued until the solution became colourless. The solid was filtered off and the solution extracted with $\mathrm{CH}_{2} \mathrm{Cl}_{2}(2 \times 75 \mathrm{~mL})$, washed with $\mathrm{H}_{2} \mathrm{O}(10 \mathrm{~mL})$, dried with anhydrous $\mathrm{Na}_{2} \mathrm{SO}_{4}$ and the solvent removed in vacuo. The residue thus obtained was subjected to flash chromatography $(20 \%$ EtOAc/toluene) to give sugar-based macrocycle $16 \beta$ as a colourless oil (163 mg, $58 \% ; \beta$ selectivity over $98 \%) . R_{\mathrm{f}}=0.42$ (35\% EtOAc/toluene). $[a]_{5}^{5}=+0.35\left(c=1, \mathrm{CHCl}_{3}\right)$. ${ }^{\prime} \mathrm{H}$ NMR $\left(\mathrm{CDCl}_{3}, 400 \mathrm{MHz}\right): \delta=$ $8.14(\mathrm{~s}, 1 \mathrm{H}$, triazole $\mathrm{H}), 7.47-7.29(\mathrm{~m}, 28 \mathrm{H}, \mathrm{Ar}-\mathrm{H}), 5.92(\mathrm{~d}, J=$ $4.0 \mathrm{~Hz}, 1 \mathrm{H}, 1 \mathrm{a}-\mathrm{H}), 5.53(\mathrm{~d}, J=14.0 \mathrm{~Hz}, 1 \mathrm{H}, N$-benzylic $\mathrm{H}), 5.45$ (d, $J=14.0 \mathrm{~Hz}, 1 \mathrm{H}, N$-benzylic H), 4.99 (d, $J=12.0 \mathrm{~Hz}, 1 \mathrm{H}$, benzylic $\mathrm{H}), 4.93-4.89(\mathrm{~m}, 3 \mathrm{H}$, benzylic $\mathrm{H}), 4.82(\mathrm{~d}, J=11.2 \mathrm{~Hz}$, $1 \mathrm{H}$, benzylic $\mathrm{H}), 4.77(\mathrm{~d}, J=11.6 \mathrm{~Hz}, 1 \mathrm{H}$, benzylic $\mathrm{H}), 4.68(\mathrm{~d}$, $J=4.0 \mathrm{~Hz}, 1 \mathrm{H}, 2 \mathrm{a}-\mathrm{H}), 4.65(\mathrm{~d}, J=12.4 \mathrm{~Hz}, 1 \mathrm{H}$, benzylic $\mathrm{H})$, 4.63-4.52 (m, $4 \mathrm{H}$, benzylic $\mathrm{H}), 4.45(\mathrm{~d}, J=11.6 \mathrm{~Hz}, 1 \mathrm{H}$, benzylic H), $4.43(\mathrm{~d}, J=7.6 \mathrm{~Hz}, 1 \mathrm{H}, 1 \mathrm{~b}-\mathrm{H}), 4.29(\mathrm{dd}, J=8.4,2.8 \mathrm{~Hz}, 1 \mathrm{H}$, $4 \mathrm{a}-\mathrm{H}), 4.25(\mathrm{dd}, J=12.0,2.0 \mathrm{~Hz}, 1 \mathrm{H}, 6 \mathrm{a}-\mathrm{H}), 4.11(\mathrm{~d}, J=2.8 \mathrm{~Hz}$,
$1 \mathrm{H}, 3 \mathrm{a}-\mathrm{H}), 4.06(\mathrm{dt}, J=7.2,2.0 \mathrm{~Hz}, 1 \mathrm{H}, 5 \mathrm{a}-\mathrm{H}), 3.85(\mathrm{dd}, J=$ $12.0,4.8 \mathrm{~Hz}, 1 \mathrm{H}, 6 \mathrm{~b}-\mathrm{H}), 3.77$ (dd, $J=11.4,2.0 \mathrm{~Hz}, 1 \mathrm{H}, 6 \mathrm{a}-\mathrm{H}$ ), $3.72-3.67\left(\mathrm{~m}, 2 \mathrm{H}, 6 \mathrm{a}^{\prime}-\mathrm{H}, 5 \mathrm{~b}-\mathrm{H}\right), 3.65(\mathrm{dd}, J=9.2 \mathrm{~Hz}, 1 \mathrm{H}, 3 \mathrm{~b}-\mathrm{H})$, $3.49(\mathrm{~m}, 1 \mathrm{H}, 4 \mathrm{~b}-\mathrm{H}), 3.42(\mathrm{dd}, J=8.4 \mathrm{~Hz}, 1 \mathrm{H}, 2 \mathrm{~b}-\mathrm{H}), 1.60$ and 1.36 [each s, each $3 \mathrm{H}, 2 \mathrm{C}\left(\mathrm{CH}_{3}\right)_{2}$ ] ppm. ${ }^{1 .} \mathrm{C} \mathrm{NMR}(100 \mathrm{MHz}): \delta$ $=145.70,138.38,138.21,138.11,137.65,137.57,132.19,131.71$, $130.48,129.47,128.89,128.51,128.04,127.99,127.94,127.88$, $127.79,127.72,127.62,125.11(\mathrm{Ar}-\mathrm{C}), 111.94\left(\mathrm{CMe}_{2}\right), 104.89(\mathrm{C}-$ 1a), 101.75 (C-1b), 86.48 (C-3b), 81.82 (C-2a, C-3a, merged), 80.25 (C-2b), 78.14 (C-4a), 78.03 (C-5b), 76.54 (C-5a), $75.73\left(\mathrm{OCH}_{2}\right)$, 74.93 (C-4b merged with $\left.\mathrm{OCH}_{2}\right), 73.47,72.02,69.54\left(\mathrm{OCH}_{2} \mathrm{Ar}\right)$, 68.66 (C-6b), 67.89 (C-6a), $66.34\left(\mathrm{OCH}_{2} \mathrm{Ar}\right), 51.87$ ( $\left.\mathrm{NCH}_{2} \mathrm{Ar}\right)$, 26.59 and $26.41\left[2 \mathrm{C}\left(\mathrm{CH}_{3}\right)_{2}\right] \mathrm{ppm}$. HRMS (+ mode): calcd. for $\mathrm{C}_{54} \mathrm{H}_{61} \mathrm{~N}_{3} \mathrm{O}_{11}[\mathrm{M}+\mathrm{H}]^{+}$926.4228; found 926.4185 .

Compounds 21 $\alpha, \beta$ : Compound $20(0.2 \mathrm{~g}, 0.193 \mathrm{mmol})$ on treatment with NIS ( $80 \mathrm{mg}, 0.38 \mathrm{mmol})$ and TMSOTf $(15 \mu \mathrm{L}, 0.076 \mathrm{mmol})$ in dry $\mathrm{CH}_{2} \mathrm{Cl}_{2}$ for $2 \mathrm{~h}$ and workup as described in general procedure $D$ afforded $21 \alpha, \beta(116 \mathrm{mg}, 65 \%)$ as a colourless oil. $\alpha / \beta=$ 1:3.

21p: $R_{\mathrm{f}}=0.35$ (30\% EtOAc/toluene). ' $\mathrm{H}$ NMR $\left(\mathrm{CDCl}_{3}, 400 \mathrm{MHz}\right)$; $\delta=7.66(\mathrm{~s}, 1 \mathrm{H}, \mathrm{Ar}-\mathrm{H}), 7.38-7.15(\mathrm{~m}, 22 \mathrm{H}, \operatorname{Ar}-\mathrm{H}), 6.89(\mathrm{~s}, 1 \mathrm{H}$, Ar-H), $6.86(\mathrm{~d}, J=7.2 \mathrm{~Hz}, 1 \mathrm{H}, \mathrm{Ar}-\mathrm{H}), 5.74(\mathrm{~d}, J=4.0 \mathrm{~Hz}, 1 \mathrm{H}$, la-H), 5.62 and 5.49 (each d, each $J=14.8 \mathrm{~Hz}$, each $1 \mathrm{H}, N$-benzylic H), $4.94(\mathrm{~d}, J=12.4 \mathrm{~Hz}, 1 \mathrm{H}$, benzylic $\mathrm{H}), 4.90(\mathrm{~d}, J=12.0 \mathrm{~Hz}$, $1 \mathrm{H}$, benzylic $\mathrm{H}), 4.85(\mathrm{~d}, J=11.6 \mathrm{~Hz}, 1 \mathrm{H}$, benzylic $\mathrm{H}), 4.80(\mathrm{~d}$, $J=11.2 \mathrm{~Hz}, 1 \mathrm{H}$, benzylic $\mathrm{H}), 4.68(\mathrm{~d}, J=10.8 \mathrm{~Hz}, 1 \mathrm{H}$, benzylic $\mathrm{H}), 4.59(\mathrm{~d}, J=12.0 \mathrm{~Hz}, 1 \mathrm{H}$, benzylic $\mathrm{H}), 4.50(\mathrm{~d}, J=4.0 \mathrm{~Hz}, 1$ $\mathrm{H}, 2 \mathrm{a}-\mathrm{H}$ ), 4.47 and 4.46 (each d, each $J=12.4 \mathrm{~Hz}$, each $1 \mathrm{H}$, benzylic $\mathrm{H}), 4.38(\mathrm{~d}, J=12.0 \mathrm{~Hz}, 1 \mathrm{H}$, benzylic $\mathrm{H}), 4.34 .4 .29(\mathrm{~m}, 4 \mathrm{H}$, 1b-H merged with 3 benzylic $\mathrm{H}), 3.99-3.96(\mathrm{~m}, 3 \mathrm{H}, 3 \mathrm{a}-\mathrm{H}, 4 \mathrm{a}-\mathrm{H}$, 5b-H), 3.81-3.79 (m, $2 \mathrm{H}, 6 \mathrm{a}-\mathrm{H}), 3.62-3.57(\mathrm{~m}, 3 \mathrm{H}, 6 \mathrm{~b}-\mathrm{H}, 5 \mathrm{a}-\mathrm{H})$, 4.53 (dd, $J=9.2 \mathrm{~Hz}, 1 \mathrm{H}, 3 \mathrm{~b}-\mathrm{H}), 3.35$ (dd, $J=9.2 \mathrm{~Hz}, 1 \mathrm{H}, 4 \mathrm{~b}-$ H), 3.27 (dd, $J=8.0,8.4 \mathrm{~Hz}, 1 \mathrm{H}, 2 \mathrm{~b}-\mathrm{H}$ ), 1.41 and 1.22 [each s, each $\left.3 \mathrm{H}, 2 \mathrm{C}\left(\mathrm{CH}_{3}\right)_{2}\right] \mathrm{ppm}$. ${ }^{\mathrm{i}} \mathrm{C}$ NMR $(100 \mathrm{MHz}): \delta=140.78$, $138.46,138.41,138.28,137.70,135.77,129.71$ (Ar-Cq), 128.49, $128.42,128.33,128.23,127.90,12.82,127.80,127.72,127.66$, $127.63,127.41,126.31,125.91,125.66(\mathrm{Ar}-\mathrm{C}), 111.78\left(\mathrm{CMe}_{2}\right)$, 105.01 (C-1a), 103.68 (C-1 b), 86.42 (C-3b), 81.96 (C-2a), 81.86 (C3a), 79.07 (C-4a), 78.33 (C-2b), 78.28 (C-5a), 75.29 ( $\left.\mathrm{CH}_{2} \mathrm{Ar}\right), 75.00$ (C-5b), 74.71, 73.55, 72.31 ( $\left.\mathrm{CH}_{2} \mathrm{Ar}\right), 72.08(\mathrm{C}-6 \mathrm{a}), 71.84\left(\mathrm{OCH}_{2}\right)$, $69.25(\mathrm{C}-6 \mathrm{~b}), 64.38\left(\mathrm{OCH}_{2}\right), 53.49\left(\mathrm{NCH}_{2} \mathrm{Ar}\right), 26.70$ and 26.39 [2 $\left.\mathrm{C}\left(\mathrm{CH}_{3}\right)_{2}\right]$ ppm. HRMS (+ mode): calcd. for $\mathrm{C}_{54} \mathrm{H}_{61} \mathrm{~N}_{3} \mathrm{O}_{11}[\mathrm{M}+$ H] ${ }^{+}$926.4228; found 926.3905 .

Compounds 29 $\alpha, \beta$ : Compound $28(0.4 \mathrm{~g}, 0.386 \mathrm{mmol})$ on treatment with NIS $(173 \mathrm{mg}, 0.773 \mathrm{mmol})$ and TMSOTf $(30 \mu \mathrm{L}, 0.16 \mathrm{mmol})$ in dry $\mathrm{CH}_{2} \mathrm{Cl}_{2}(15 \mathrm{~mL})$ for $2 \mathrm{~h}$ and workup as described in general procedure $\mathrm{D}$ afforded an anomeric mixture of $29 \alpha, \beta(286 \mathrm{mg}, 80 \%)$ as a colourless oil. The anomers could not be separated. $\alpha / \beta=3: 2$. $R_{\mathrm{f}}=0.35$ (30\% EtOAc/toluene); both anomers have the same $R_{\mathrm{f}}$ on TLC. 'H NMR $\left(\mathrm{CDCl}_{3}, 400 \mathrm{MHz}\right): \delta=8.08(\mathrm{~s}, 1 \mathrm{H}$, triazole $\mathrm{H}$, minor isomer), 7.43-7.06 ( $\mathrm{m}, 25 \mathrm{H}, \mathrm{Ar}-\mathrm{H}$, major and minor isomer, triazole $\mathrm{H}$, minor isomer), $5.84(\mathrm{~d}, J=3.6 \mathrm{~Hz}, 1 \mathrm{H}, 1 \mathrm{a}-\mathrm{H}$, major isomer), 5.79 (d, $J=3.6 \mathrm{~Hz}, \mathrm{I} \mathrm{H}, 1 \mathrm{~d}-\mathrm{H}$, minor isomer), 5.62 (d, $J=14.4 \mathrm{~Hz}, 1 \mathrm{H}, \mathrm{N}$-benzylic $\mathrm{H}$, major isomer), 5.48 (s, $2 \mathrm{H}$, $\mathrm{NCH}_{2} \mathrm{Ar}$, minor isomer), 5.39 (d, $J=14.4 \mathrm{~Hz}, 1 \mathrm{H}, \mathrm{N}$-benzylic $\mathrm{H}$, major isomer), $5.05(\mathrm{~d}, J=13.6 \mathrm{~Hz}, 1 \mathrm{H}$, benzylic $\mathrm{H}$, minor isomer), 4.95 (d, $J=4.4 \mathrm{~Hz}, 1 \mathrm{H}, 1 \mathrm{~b}-\mathrm{H}$, major isomer), 4.93 (d, $J=$ $12.0 \mathrm{~Hz}, \mathrm{I} \mathrm{H}$, benzylic $\mathrm{H}$, major isomer), $4.91(\mathrm{~d}, J=11.2 \mathrm{~Hz}, 1$ $\mathrm{H}$, benzylic $\mathrm{H}$, major isomer), $4.88(\mathrm{~d}, J=10.8 \mathrm{~Hz}, 1 \mathrm{H}$, benzylic $\mathrm{H}$, major isomer), 4.85 and 4.83 (each d, each $J=12.4 \mathrm{~Hz}$, each 1 $\mathrm{H}$, benzylic $\mathrm{H}$, major isomer), $4.64(\mathrm{~d}, J=12.8 \mathrm{~Hz}, 1 \mathrm{H}$, benzylic $\mathrm{H}$, minor isomer), 4.59-4.52 ( $\mathrm{m}, 3 \mathrm{H}$, benzylic $\mathrm{H}$, major and minor 
isomer), $4.50(\mathrm{~d}, J=4.0 \mathrm{~Hz}, 1 \mathrm{H}, 2 \mathrm{a}-\mathrm{H}$, major isomer $), 4.46-4.30$ (m, $4 \mathrm{H}, 2 \mathrm{a}-\mathrm{H}, 3 \mathrm{a}-\mathrm{H}$, minor isomer, 4a-H, major isomer), 4.26 (d, $J=8.0 \mathrm{~Hz}, 1 \mathrm{H}, 1 \mathrm{~b}-\mathrm{H}$, minor isomer), 4.21 (dd, $J=9.6,4.0 \mathrm{~Hz}, 1$ $\mathrm{H}$, major isomer), $4.15-4.13(\mathrm{~m}, 2 \mathrm{H}, 5 \mathrm{~b}-\mathrm{H}$, major and minor isomer), $3.89(\mathrm{~d}, J=2.8 \mathrm{~Hz}, 1 \mathrm{H}, 3 \mathrm{a}-\mathrm{H}$, major isomer), $3.74(\mathrm{dd}, J=$ $10.8,1.6 \mathrm{~Hz}, 1 \mathrm{H}, 6^{\prime} \mathrm{b}-\mathrm{H}$, major isomer $), 3.70-3.66(\mathrm{~m}, 2 \mathrm{H}, 6 \mathrm{~b}-\mathrm{H}$ minor isomer, $4 \mathrm{~b}-\mathrm{H}$, major isomer), 3.62 (dd, $J=9.2,1.6 \mathrm{~Hz}, 6 \mathrm{a}-$ $\mathrm{H}), 3.50-3.32(\mathrm{~m}, 3 \mathrm{H}, 2 \mathrm{~b}-\mathrm{H}, 3 \mathrm{~b}-\mathrm{H}$, major and minor isomer, $4 \mathrm{~b}$ $\mathrm{H}$, minor isomer), $3.20(\mathrm{~m}, 1 \mathrm{H}, 5 \mathrm{a}-\mathrm{H}$, minor isomer $), 1.45$ and 1.20 [each s, each $3 \mathrm{H}, 2 \mathrm{C}\left(\mathrm{CH}_{3}\right)_{2}$, minor isomer], 1.40 and 1.26 [each s, each $3 \mathrm{H}, 2 \mathrm{C}\left(\mathrm{CH}_{3}\right)_{2}$, major isomer] ppm. ${ }^{13} \mathrm{C} \mathrm{NMR}$ $(100 \mathrm{MHz}): \delta=146.71,145.41,138.97,138.54,138.30,138.25$, $138.06,137.61,137.26,136.93,133.26,133.25,132.56,132.21$, $131.81,131.44,129.79,129.35,129.28,129.24,129.10,128.56$, $128.50,128.44,128.42,128.41,128.38,128.35,128.11,128.03$, $127.94,127.92,127.89,127.86,127.33,125.34,124.32,123.60$ (Ar$\mathrm{C}$, major and minor isomer), $111.74\left(\mathrm{CMe}_{2}\right.$, major isomer $), 111.71$ ( $\mathrm{CMe}_{2}$, minor isomer), 104.78 (C-la, merged for major and minor isomer), 102.53 (C-1b, minor isomer), 94.86 (C-1b, major isomer), 85.59 (C-2b, minor isomer), 84.31 (C-4b, minor isomer), 82.49, $81.99,81.89,81.85,81.46,81.01,80.35,78.08,78.92,77.63,76.48$, $75.66,74.89,74.69,74.11,73.62,73.49,72.07,71.60,71.59,71.56$, $71.49,70.70$ (C-5a, major isomer), 69.59, 69.27, 68.55, 68.12, 66.64 (C-6, minor isomer), $52.72\left(\mathrm{NCH}_{2}\right.$, major isomer), $51.79\left(\mathrm{NCH}_{2}\right.$, minor isomer), $29.72,26.97,26.89,26.43\left(2 \mathrm{CH}_{3}\right.$, major and minor isomer) ppm. HRMS (+ mode): calcd. for $\mathrm{C}_{54} \mathrm{H}_{61} \mathrm{~N}_{3} \mathrm{O}_{11}[\mathrm{M}+\mathrm{H}]^{+}$ 926.4228; found 926.3927 .

Compounds 34o. and 34p: Compound $33(0.7 \mathrm{~g}, 0.68 \mathrm{mmol})$ on treatment with NIS $(0.24 \mathrm{~g}, 1.35 \mathrm{mmol})$ and TMSOTf $(35 \mu \mathrm{L}$, $0.19 \mathrm{mmol})$ in dry $\mathrm{CH}_{2} \mathrm{Cl}_{2}(20 \mathrm{~mL})$ for $2 \mathrm{~h}$ and workup as described in general procedure D afforded $34 a, \beta$ as a colourless oil $(313 \mathrm{mg}$, $50 \%$ ). The two anomers were successfully separated in pure form $(\alpha / \beta=2: 1)$ and characterized by their spectroscopic data.

34a: Colourless oil. $R_{\mathrm{r}}=0.68\left(30 \% \mathrm{EtOAc} /\right.$ toluene). ${ }^{1} \mathrm{H}$ NMR $\left(\mathrm{CDCl}_{3}, 400 \mathrm{MHz}\right): \delta=7.43(\mathrm{dd}, J=8.0,2.0 \mathrm{~Hz}, 2 \mathrm{H}, \mathrm{Ar}-\mathrm{H}), 7.29$ $7.27(\mathrm{~m}, 23 \mathrm{H}, \mathrm{Ar}-\mathrm{H}), 5.81(\mathrm{~d}, J=4.0 \mathrm{~Hz}, 1 \mathrm{H}, 1 \mathrm{a}-\mathrm{H}), 5.37$ and 5.32 (each d, each $J=14.8 \mathrm{~Hz}$, each $1 \mathrm{H}, N$-benzylic $\mathrm{H}$ ), 4.90 and 4.84 (each d, each $J=11.6 \mathrm{~Hz}$, each $1 \mathrm{H}$, benzylic $\mathrm{H}$ ), 4.81 (d, $J$ $=10.8 \mathrm{~Hz}, 1 \mathrm{H}$, benzylic $\mathrm{H}$ ), 4.71 and 4.72 (each $\mathrm{d}$, each $J=$ $10.8 \mathrm{~Hz}$, each $1 \mathrm{H}$, benzylic $\mathrm{H}), 4.59(\mathrm{~d}, J=12.4 \mathrm{~Hz}, 1 \mathrm{H}$, benzylic H), $4.53-4.52(\mathrm{~m}, 2 \mathrm{H}, 1 \mathrm{~b}-\mathrm{H}$ merged with benzylic $\mathrm{H}), 4.50(\mathrm{~d}, J$ $=4.0 \mathrm{~Hz}, 2 \mathrm{a}-\mathrm{H}), 4.49-4.43(\mathrm{~m}, 4 \mathrm{H}$, benzylic $\mathrm{H}), 4.41(\mathrm{~d}, J=$ $12.4 \mathrm{~Hz}, 1 \mathrm{H}$, benzylic $\mathrm{H}), 4.18-4.11(\mathrm{~m}, 2 \mathrm{H}, 5 \mathrm{~b}-\mathrm{H}, 4 \mathrm{a}-\mathrm{H}), 3.98$ $(\mathrm{d}, J=2.8 \mathrm{~Hz}, 1 \mathrm{H}, 3 \mathrm{a}-\mathrm{H}), 3.69(\mathrm{dd}, j=10.8,2.0 \mathrm{~Hz}, 1 \mathrm{H}, 6 \mathrm{a}-\mathrm{H})$, $3.65,3.69$ (dd, $J=10.8,6.4 \mathrm{~Hz}, 1 \mathrm{H}, 6 \mathrm{~b}-\mathrm{H}), 3.62(\mathrm{dd}, J=10.8$, $3.6 \mathrm{~Hz}, 1 \mathrm{H}, 6 \mathrm{a}^{\prime}-\mathrm{H}$ ), 3.57-3.51 (dd, $J=8.4 \mathrm{~Hz}, 2 \mathrm{H}, 3 \mathrm{~b}-\mathrm{H}$ merged with $5 \mathrm{~b}-\mathrm{H}$ ), 3.45 (dd, $\left.J=10.0,5.6 \mathrm{~Hz}, 1 \mathrm{H}, 6 \mathrm{~b}^{\prime}-\mathrm{H}\right), 3.42-3.38(\mathrm{~m}$, $2 \mathrm{H}, 2 \mathrm{~b}-\mathrm{H}, 4 \mathrm{~b}-\mathrm{H}), 1.42$ and 1.22 [each s, each $3 \mathrm{H}, 2 \mathrm{C}\left(\mathrm{CH}_{3}\right)_{2}$ ] ppm. ${ }^{1.3} \mathrm{C}$ NMR $(100 \mathrm{MHz}): \delta=138.91,137.70,137.65,137.42,137.05$, 134.02 and $132.92(\mathrm{Cq}), 131.28,128.39,128.22,127.95,127.79$, $127.77,127.75,127.68,127.24,127.13,127.01,126.98,126.88$, $126.79,126.74,126.48,126.45,121.96(\mathrm{Ar}-\mathrm{C}), 111.11\left(\mathrm{CMe}_{2}\right)$, 104.63 (C-1a), 86.50 (C-1b), 85.81 (C-3b), 81.32 (C-3a), 80.91 (C2a), 80.32 (C-2b), 79.59 (C-4a), 78.48 (C-4b), 77.09 (C-5b), 75.05, $74.37,72.76,72.71,72.08$ and $71.41\left(\mathrm{CH}_{2} \mathrm{Ar}, \mathrm{OCH}_{2} \mathrm{Ph}, \mathrm{C}-6 \mathrm{a}\right)$, 68.41 (C-6b), 68.39 (C-5a), 66.05 ( $\left.\mathrm{OCH}_{2} \mathrm{Ar}\right), 53.36\left(\mathrm{NCH}_{2} \mathrm{Ar}\right)$, 26.15 and $25.67\left[2 \mathrm{C}\left(\mathrm{CH}_{3}\right)_{2}\right]$ ppm. HRMS (+ mode): calcd. for $\mathrm{C}_{54} \mathrm{H}_{61} \mathrm{~N}_{3} \mathrm{O}_{11}[\mathrm{M}+\mathrm{H}]^{+} 926.4228$; found 926.3862 .

34p: Colourless oil. $R_{f}=0.55\left(30 \%\right.$ EtOAc/toluene). ${ }^{1} \mathrm{H}$ NMR $\left(\mathrm{CDCl}_{3}, 400 \mathrm{MHz}\right): \delta=7.42(\mathrm{~d}, J=8.0 \mathrm{~Hz}, 1 \mathrm{H}, \mathrm{Ar}-\mathrm{H}), 7.28-7.18$ (m, $22 \mathrm{H}, \mathrm{Ar}-\mathrm{H}), 7.10(\mathrm{~d}, J=8.0 \mathrm{~Hz}, 1 \mathrm{H}, \mathrm{Ar}-\mathrm{H}), 6.67(\mathrm{~s}, 1 \mathrm{H}, \mathrm{Ar}-$ H), $5.80(\mathrm{~d}, J=3.6 \mathrm{~Hz}, 1 \mathrm{H}, 1 \mathrm{a}-\mathrm{H}$ ), 5.67 and 5.23 (each d, each $J$
$=15.6 \mathrm{~Hz}$, each $1 \mathrm{H}, N$-benzylic $\mathrm{H}$ ), 4.84 and 4.80 (each d, each $J$ $=11.2 \mathrm{~Hz}$, each $1 \mathrm{H}$, benzylic $\mathrm{H}), 4.76(\mathrm{~d}, J=8.4 \mathrm{~Hz}, 1 \mathrm{H}, 1 \mathrm{~b}-\mathrm{H})$, 4.74 and 4.73 (each d, each $J=11.2 \mathrm{~Hz}$, each $1 \mathrm{H}$, benzylic $\mathrm{H}$ ), $4.65(\mathrm{~d}, J=13.6 \mathrm{~Hz}, 1 \mathrm{H}$, benzylic $\mathrm{H}), 4.60(\mathrm{~d}, J=11.6 \mathrm{~Hz}, 1 \mathrm{H}$, benzylic $\mathrm{H}), 4.58(\mathrm{~d}, J=12.0 \mathrm{~Hz}, 1 \mathrm{H}$, benzylic $\mathrm{H}), 4.53(\mathrm{~d}, J=$ $12.4 \mathrm{~Hz}, 1 \mathrm{H}$, benzylic $\mathrm{H}$ ), $4.49(\mathrm{~d}, J=12.4 \mathrm{~Hz}, 1 \mathrm{H}$, benzylic $\mathrm{H}$ ), $4.48-4.45$ (m, $2 \mathrm{H}$, benzylic $\mathrm{H}), 4.44(\mathrm{~d}, J=3.2 \mathrm{~Hz}, 2 \mathrm{a}-\mathrm{H}), 4.42$ (d, $J=10.8 \mathrm{~Hz}, 1 \mathrm{H}$, benzylic $\mathrm{H}), 4.39(\mathrm{~d}, J=12.4 \mathrm{~Hz}, 1 \mathrm{H}$, benzylic H), 4.25 (d, $J=12.4 \mathrm{~Hz}, 1 \mathrm{H}$, benzylic H), 3.95-3.91 (m, $3 \mathrm{H}, 3 \mathrm{a}-$ $\mathrm{H}, 4 \mathrm{a}-\mathrm{H}, 5 \mathrm{~b}-\mathrm{H}), 3.82(\mathrm{dd}, J=10.4,4.4 \mathrm{~Hz}, 1 \mathrm{H}, 6 \mathrm{a}-\mathrm{H}), 3.81-3.74$ $\left(\mathrm{m}, 3 \mathrm{H}, 5 \mathrm{a}-\mathrm{H}, 3 \mathrm{~b}-\mathrm{H}, 6 \mathrm{~b}^{\prime}-\mathrm{H}\right), 3.55$ (dd, $J=8.4,4.4 \mathrm{~Hz}, 1 \mathrm{H}, 6{ }^{\prime} \mathrm{a}-$ H), $3.54-3.48\left(\mathrm{~m}, 3 \mathrm{H}, 6^{\prime} \mathrm{b}-\mathrm{H}, 4 \mathrm{~b}-\mathrm{H}, 2 \mathrm{~b}-\mathrm{H}\right), 1.40$ and 1.22 [each $\mathrm{s}$, each $\left.3 \mathrm{H}, 2 \mathrm{C}\left(\mathrm{CH}_{3}\right)_{2}\right] \mathrm{ppm} .{ }^{13} \mathrm{C}$ NMR $(100 \mathrm{MHz}) ; \delta=140.54$, $138.94,138.51,138.26,138.24,133.71$ and $129.12(\mathrm{Ar}-\mathrm{Cq}), 128.41$, $128.32,128.09,127.81,127.78,127.61,127.54,127.22,127.20$, $126.87,125.89,124.98(\mathrm{Ar}-\mathrm{C}), 111.95\left(\mathrm{CMe}_{2}\right), 105.09(\mathrm{C}-1 \mathrm{a}), 96.70$ (C-1b), 82.69 (C-2a), 82.20 (C-3a), 81.48 (C-4a), 79.76 (C-2b), 79.17 (C-3a), 78.39 (C-4b), 77.23 (C-5b), 75.52, 75.15, 73.40, 73.03 $\left(\mathrm{CH}_{2} \mathrm{Ar}, \mathrm{OCH}_{2} \mathrm{Ph}\right), 72.78(\mathrm{C}-6 \mathrm{a}), 72.32\left(\mathrm{OCH}_{2}\right), 70.92(\mathrm{C}-5 \mathrm{a})$, 68.97 (C-6b), $53.54\left(\mathrm{NCH}_{2} \mathrm{Ar}\right), 26.89$ and $26.30\left[2 \mathrm{C}\left(\mathrm{CH}_{3}\right)_{2}\right] \mathrm{ppm}$. HRMS ( + mode): calcd. for $\mathrm{C}_{54} \mathrm{H}_{61} \mathrm{~N}_{3} \mathrm{O}_{11}[\mathrm{M}+\mathrm{H}]^{+} 926.4228$; found 926.3962 .

Compound 40a: Compound $39(1.0 \mathrm{~g}, 0.953 \mathrm{mmol})$ on treatment with NIS (427 mg, $1.90 \mathrm{mmol})$ and TMSOTf $(35 \mu \mathrm{L}, 0.19 \mathrm{mmol})$ in dry $\mathrm{CH}_{2} \mathrm{Cl}_{2}$ for $4 \mathrm{~h}$ and workup as described in general procedure D afforded $40 \alpha$ as a colourless oil $(180 \mathrm{mg}, 20 \%) . R_{\mathrm{f}}=0.54$ (30\% EtOAc/toluene). $[a]_{\mathrm{D}}^{25}=+0.47\left(c=1, \mathrm{CHCl}_{3}\right)$. ${ }^{1} \mathrm{H} \mathrm{NMR}$ $\left(\mathrm{CDCl}_{3}, 400 \mathrm{MHz}\right): \delta=8.03(\mathrm{~d}, J=8.4 \mathrm{~Hz}, 2 \mathrm{H}, \mathrm{Ar}-\mathrm{H}), 7.50-7.18$ $(\mathrm{m}, 23 \mathrm{H}, \mathrm{Ar}-\mathrm{H}), 5.93(\mathrm{~d}, J=3.6 \mathrm{~Hz}, 1 \mathrm{H}, \mathrm{la}-\mathrm{H}), 5.65$ and 5.36 (each d, each $J=15.2 \mathrm{~Hz}$, each $1 \mathrm{H}, N$-benzylic $\mathrm{H}), 4.96(\mathrm{~d}, J=$ $11.6 \mathrm{~Hz}, 1 \mathrm{H}$, benzylic $\mathrm{H}$ ), 4.91 and 4.87 (each d, each $J=10.8 \mathrm{~Hz}$, $1 \mathrm{H}$, benzylic $\mathrm{H}), 4.85-4.77(\mathrm{~m}, 3 \mathrm{H}$, benzylic $\mathrm{H}), 4.71(\mathrm{~d}, J=$ $3.6 \mathrm{~Hz}, 1 \mathrm{H}, 2 \mathrm{a}-\mathrm{H}), 4.65\left(\mathrm{dd}, J=9.6,4.8 \mathrm{~Hz}, 1 \mathrm{H}, 6 \mathrm{a}^{\prime}-\mathrm{H}\right), 4.59$ (d, $J=11.6 \mathrm{~Hz}, 1 \mathrm{H}$, benzylic $\mathrm{H}), 4.57-4.54(\mathrm{~m}, 3 \mathrm{H}, 1-\mathrm{H}$ merged with benzylic $\mathrm{H}), 4.52(\mathrm{~d}, J=12.0 \mathrm{~Hz}, 1 \mathrm{H}$, benzylic $\mathrm{H}), 4.44(\mathrm{~d}, J=$ $11.6 \mathrm{~Hz}, 1 \mathrm{H}$, benzylic $\mathrm{H}), 4.33-4.28\left(\mathrm{~m}, 2 \mathrm{H}, 5 \mathrm{a}-\mathrm{H}, 6 \mathrm{~b}^{t}-\mathrm{H}\right), 4.25$ (dd, $J=8.8,2.8 \mathrm{~Hz}, 1 \mathrm{H}, 4 \mathrm{a}-\mathrm{H}), 4.06(\mathrm{~d}, J=2.8 \mathrm{~Hz}, 1 \mathrm{H}, 3 \mathrm{a}-\mathrm{H}$ ), 3.76 (dd, $J=10.8,1.6 \mathrm{~Hz}, 1 \mathrm{H}, 6 \mathrm{a}-\mathrm{H}), 3.69(\mathrm{dd}, J=10.8,4.8 \mathrm{~Hz}$, $1 \mathrm{H}, 6 \mathrm{~b}-\mathrm{H}), 3.64(\mathrm{~m}, 1 \mathrm{H}, 5 \mathrm{~b}-\mathrm{H}), 3.61(\mathrm{dd}, J=9.2 \mathrm{~Hz}, 1 \mathrm{H}, 3 \mathrm{~b}-\mathrm{H})$, 3.48-3.44 (m, $2 \mathrm{H}, 4 \mathrm{~b}-\mathrm{H}, 2 \mathrm{~b}-\mathrm{H}), 1.50$ and 1.32 [each $\mathrm{s}$, each $3 \mathrm{H}$, $\left.2 \mathrm{C}\left(\mathrm{CH}_{3}\right)_{2}\right] \mathrm{ppm} .{ }^{13} \mathrm{C}$ NMR $(100 \mathrm{MHz}): \delta=165.93(\mathrm{C}=\mathrm{O}), 137.89$, $137.80,137.57,135.62,133.09,132.54,132.39(\mathrm{Ar}-\mathrm{Cq}), 131.44$, $129.84,129.53,129.37,129.20,128.63,128.49,128.43,127.98$, $127.97,127.88,127.44,127.39,127.19,127.10,127.00(\mathrm{Ar}-\mathrm{C})$, $111.41\left(\mathrm{CMe}_{2}\right), 104.84(\mathrm{C}-1 \mathrm{a}), 86.67$ (C-1b), 86.01 (C-5b), 81.85 (C-3a), 80.59 (C-2b), $80.20(\mathrm{C}-2 \mathrm{a}), 79.78(\mathrm{C}-4 \mathrm{a}), 78.65(\mathrm{C}-4 \mathrm{~b})$, $77.27(\mathrm{C}-3 \mathrm{~b}), 75.23,74.58,72.96\left(\mathrm{CH}_{2} \mathrm{Ar}\right), 69.26(\mathrm{C}-6 \mathrm{a}), 68.33(\mathrm{C}-$ 6b), $67.33\left(\mathrm{OCH}_{2} \mathrm{Ar}\right), 67.24(\mathrm{C}-5 \mathrm{a}), 66.26\left(\mathrm{OCH}_{2} \mathrm{Ar}\right), 50.92$ ( $\left.\mathrm{NCH}_{2} \mathrm{Ar}\right), 26.23$ and $25.86\left[2 \mathrm{C}\left(\mathrm{CH}_{3}\right)_{2}\right]$ ppm. HRMS (+ mode): calcd. for $\mathrm{C}_{54} \mathrm{H}_{59} \mathrm{~N}_{3} \mathrm{O}_{12}[\mathrm{M}+\mathrm{H}]^{+} 940.4021$; found 940.3940 .

Compounds 51 $\alpha$ and 51p: Compound $50(0.76 \mathrm{~g}, 0.69 \mathrm{mmol})$ on treatment with NIS $(309 \mathrm{mg}, 1.38 \mathrm{mmol})$ and TMSOTf $(35 \mu \mathrm{L}$, $0.19 \mathrm{mmol}$ ) in dry $\mathrm{CH}_{2} \mathrm{Cl}_{2}$ for $2 \mathrm{~h}$ and workup as described in general procedure $\mathrm{D}$ afforded $51 \alpha$ and $51 \beta$ as a colourless oil $(0.65 \mathrm{~g}$, $95 \%$ ). $\alpha / \beta=1: 2$. Compounds $51 a$ and $51 \beta$ were successfully separated in pure form and characterized by comparing their spectroscopic data.

51a: Colourless oil. $R_{\mathrm{f}}=0.40$ (30\% EtOAc/toluene). $[\alpha]_{\mathrm{n}}^{25}=+26.0$ $\left(c=1, \mathrm{CHCl}_{3}\right)$. 'H NMR $\left(\mathrm{CDCl}_{3}, 400 \mathrm{MHz}\right): \delta=7.46(\mathrm{dd}, J=$ $7.6,0.8 \mathrm{~Hz}, 1 \mathrm{H}, \mathrm{Ar}-\mathrm{H}), 7.44(\mathrm{~s}, 1 \mathrm{H}$, triazole $\mathrm{H}), 7.32-7.15(\mathrm{~m}, 25$ $\mathrm{H}, \mathrm{Ar}-\mathrm{H}), 7.09(\mathrm{~d}, J=7.6,1.2 \mathrm{~Hz}, 1 \mathrm{H}, \mathrm{Ar}-\mathrm{H}), 7.03(\mathrm{dd}, J=8.0$, $2.4 \mathrm{~Hz}, 2 \mathrm{H}, \mathrm{Ar}-\mathrm{H}), 5.47\left(\mathrm{~s}, 2 \mathrm{H}, \mathrm{NCH}_{2}\right), 5.02(\mathrm{~d}, J=10.8 \mathrm{~Hz}, 1$ 
$\mathrm{H}$, benzylic H), 5.00 (d, $J=12.0 \mathrm{~Hz}, 1 \mathrm{H}$, benzylic H), 4.97 (d, $J$ $=12.8 \mathrm{~Hz}, 1 \mathrm{H}$, benzylic $\mathrm{H}$ ), 4.81 and 4.80 (each d, each $J=$ $11.2 \mathrm{~Hz}$, each $1 \mathrm{H}$, benzylic $\mathrm{H}), 4.72(\mathrm{~d}, J=11.2 \mathrm{~Hz}, 1 \mathrm{H}$, benzylic H), $4.65(\mathrm{~d}, J=12.0 \mathrm{~Hz}, 1 \mathrm{H}$, benzylic $\mathrm{H}), 4.54(\mathrm{~d}, J=10.0 \mathrm{~Hz}, 1$ $\mathrm{H}$, benzylic $\mathrm{H}$ ), 4.57 and 4.55 (each d, each $J=12.0 \mathrm{~Hz}$, each $1 \mathrm{H}$, benzylic H), $4.50(\mathrm{~d}, J=14.0 \mathrm{~Hz}, 1 \mathrm{H}$, benzylic $\mathrm{H}), 4.46(\mathrm{~d}, J=$ $3.2 \mathrm{~Hz}, 1 \mathrm{H}, 1 \mathrm{~b}-\mathrm{H}), 4.43$ (d, $J=12.0 \mathrm{~Hz}, 1 \mathrm{H}$, benzylic $\mathrm{H}$ ), 4.38 (d, $J=10.8 \mathrm{~Hz}, 1 \mathrm{H}$, benzylic H), $4.30(\mathrm{~d}, J=12.4 \mathrm{~Hz}, 1 \mathrm{H}$, benzylic H), $3.98(\mathrm{dd}, J=9.2,8.4 \mathrm{~Hz}, 1 \mathrm{H}, 3 \mathrm{~b}-\mathrm{H}), 3.82(\mathrm{~d}, J=3.6 \mathrm{~Hz}, 1 \mathrm{H}$, $1 \mathrm{a}-\mathrm{H}), 3.70-3.60(\mathrm{~m}, 3 \mathrm{H}, 3 \mathrm{a}-\mathrm{H}, 5 \mathrm{~b}-\mathrm{H}, 5 \mathrm{a}-\mathrm{H}), 3.53(\mathrm{dd}, J=10.0$, $4.0 \mathrm{~Hz}, 1 \mathrm{H}, 6 \mathrm{a}-\mathrm{H}), 3.46-3.34(\mathrm{~m}, 4 \mathrm{H}, 2 \mathrm{~b}-\mathrm{H}, 2 \mathrm{a}-\mathrm{H}, 4 \mathrm{a}-\mathrm{H}, 6 \mathrm{~b}-\mathrm{H})$, $3.30\left(\mathrm{~s}, 3 \mathrm{H}, \mathrm{OCH}_{3}\right), 3.15$ (dd, $\left.J=10.0,6.8 \mathrm{~Hz}, 1 \mathrm{H}, 6 \mathrm{a}-\mathrm{H}\right), 3.07$ (dd, $J=10.8,8.4 \mathrm{~Hz}, 1 \mathrm{H}, 4 \mathrm{~b}-\mathrm{H}), 2.40\left(\mathrm{~d}, J=10.0 \mathrm{~Hz}, 1 \mathrm{H}, 6 \mathrm{~b}^{\prime}-\right.$ H) ppm. ${ }^{1 .} \mathrm{C}$ NMR $(100 \mathrm{MHz}): \delta=147.56,139.19,138.53,138.43$, $138.30,138.10,135.86,133.54$ (Ar-Cq), 131.14, 130.86, 129.65, $129.03,128.52,128.31,128.29,128.27,128.08,127.99,127.81$, $127.78,127.53,122.88$ (Ar-C), $97.96(\mathrm{C}-1 \mathrm{a}), 97.28$ (C-1b), 84.00 (C2a), 82.63 (C-3b), 81.72 (C-3a), 80.24 (C-2b), 77.55 (C-4a), 77.42 (C-4b), 75.68, 75.43, 74.88, 73.31, 73.14, 71.92 $\left(\mathrm{OCH}_{2} \mathrm{Ar}\right), 70.99$ (C-5b), 70.12 (C-5a), 69.14 (C-6b), 68.77 (C-6a), $66.67\left(\mathrm{OCH}_{2} \mathrm{Ar}\right)$, $55.19\left(\mathrm{OCH}_{3}\right), 50.60\left(\mathrm{NCH}_{2} \mathrm{Ar}\right)$ ppm. HRMS (+ mode): calcd. for $\mathrm{C}_{59} \mathrm{H}_{65} \mathrm{~N}_{3} \mathrm{O}_{11}[\mathrm{M}+\mathrm{H}]^{+} 990.454 \mathrm{I}$; found 990.4512 .

51ß: Colourless oil. $R_{\mathrm{f}}=0.34$ (30\% EtOAc/toluene). $[a]_{\mathrm{D}}^{25}=-11.3$ $\left(c=1, \mathrm{CHCl}_{3}\right)$. 'H NMR $\left(\mathrm{CDCl}_{3}, 400 \mathrm{MHz}\right): \delta=7.36(\mathrm{~s}, 1 \mathrm{H}$, triazole H), $7.31-7.16(\mathrm{~m}, 27 \mathrm{H}, \mathrm{Ar}-\mathrm{H}), 7.07(\mathrm{dd}, J=7.6,2.0 \mathrm{~Hz}$, $1 \mathrm{H}, \mathrm{Ar}-\mathrm{H}$ ), 5.37 and 5.27 (each d, each $J=14.4 \mathrm{~Hz}$, each $1 \mathrm{H}, \mathrm{N}$ benzylic $\mathrm{H}), 4.92(\mathrm{~d}, J=12.4 \mathrm{~Hz}, 1 \mathrm{H}$, benzylic $\mathrm{H}), 4.92(\mathrm{~d}, J=$ $13.2 \mathrm{~Hz}, 1 \mathrm{H}$, benzylic H), 4.82-4.75 (m, $3 \mathrm{H}$, benzylic $\mathrm{H}), 4.69(\mathrm{~d}$, $J=10.8 \mathrm{~Hz}, 1 \mathrm{H}$, benzylic $\mathrm{H}$ ), 4.68 and 4.66 (each $\mathrm{d}$, each $J=$ $12.0 \mathrm{~Hz}$, each $1 \mathrm{H}$, benzylic $\mathrm{H}), 4.64(\mathrm{~d}, J=12.8 \mathrm{~Hz}, \mathrm{I} \mathrm{H}$, benzylic $\mathrm{H}), 4.52(\mathrm{~d}, J=12.0 \mathrm{~Hz}, 1 \mathrm{H}$, benzylic $\mathrm{H}), 4.49-4.42(\mathrm{~m}, 3 \mathrm{H}$, Ia$\mathrm{H}$ merged with two benzylic $\mathrm{H}), 4.40(\mathrm{~d}, J=12.0 \mathrm{~Hz}, 1 \mathrm{H}$, benzylic $\mathrm{H}), 4.14(\mathrm{~d}, J=7.2 \mathrm{~Hz}, 1 \mathrm{H}, \mathrm{lb}-\mathrm{H}), 4.9(\mathrm{~d}, J=12.8 \mathrm{~Hz}, 1 \mathrm{H}$, benzylic H), 3.87 (dd, $J=9.2 \mathrm{~Hz}, 1 \mathrm{H}, 3 \mathrm{~b}-\mathrm{H}), 3.64$ (dd, $J=11.6$, $3.6 \mathrm{~Hz}, 1 \mathrm{H}, 6 \mathrm{a}-\mathrm{H}), 3.60-3.45(\mathrm{~m}, 6 \mathrm{H}, 6 \mathrm{~b}-\mathrm{H}, 6 \mathrm{a}-\mathrm{H}, 4 \mathrm{a}-\mathrm{H}, 5 \mathrm{~b}-\mathrm{H}$, $3 \mathrm{a}-\mathrm{H}), 3.39$ (dd, $J=9.6,3.2 \mathrm{~Hz}, 1 \mathrm{H}, 2 \mathrm{a}-\mathrm{H}), 3.33-3.28(\mathrm{~m}, 3 \mathrm{H}, 2 \mathrm{~b}-$ $\mathrm{H}, 4 \mathrm{~b}-\mathrm{H}, 5 \mathrm{a}-\mathrm{H}), 3.26$ (s, $3 \mathrm{H}, \mathrm{OCH}_{3}$ ) ppm. ${ }^{13} \mathrm{C} \mathrm{NMR}(100 \mathrm{MHz}) ;$ $=145.97,138.76,138.42,138.35,138.31,138.15,138.02,131.35$ (Ar-Cq) $131.05,129.42,128.49,128.45,128.42,128.40,128.39$, $128.05,128.01,127.94,127.87,127.82,127.76,127.72,127.60$, 127.56, 123.28 (Ar-C), $101.76(\mathrm{C}-1 \mathrm{~b}), 98.20$ (C-1a), 85.68 (C-3a), 81.96 (C-4b), 81.47 (C-3b), 79.88 (C-2a), 78.78 (C-2b), 77.97 (C$4 a), 75.38\left(\mathrm{OCH}_{2} \mathrm{Ar}\right), 75.36$ (C-5a), 75.25, 74.86, 73.47, 73.26, 71.23 $\left(\mathrm{OCH}_{2} \mathrm{Ar}\right), 70.37(\mathrm{C}-5 \mathrm{~b}), 69.11$ and $69.06(\mathrm{C}-6 \mathrm{~b}, \mathrm{C}-6 \mathrm{a}), 66.79$ $\left(\mathrm{OCH}_{2}\right), 55.61\left(\mathrm{OCH}_{3}\right), 52.27\left(\mathrm{NCH}_{2} \mathrm{Ar}\right) \mathrm{ppm}$. HRMS (+ mode): calcd. for $\mathrm{C}_{59} \mathrm{H}_{65} \mathrm{~N}_{3} \mathrm{O}_{11}[\mathrm{M}+\mathrm{H}]^{+} 990.4541$; found 990.4489 .

Compounds 56a and 56ß: Compound $55(0.7 \mathrm{mg}, 0.63 \mathrm{mmol})$ on treatment with NIS $(0.3 \mathrm{mg}, 1.27 \mathrm{mmol})$ and TMSOTf $(40 \mu \mathrm{L}$, $0.20 \mathrm{mmol})$ in dry $\mathrm{CH}_{2} \mathrm{Cl}_{2}(30 \mathrm{~mL})$ for $2 \mathrm{~h}$ and workup as described in general procedure D afforded 560 and $56 \beta$ as a colourless oil $(0.5 \mathrm{mg}, 80 \%)$. The two compounds were successfully separated in pure form and characterized by their spectroscopic data. The configuration of glycosidation product $\mathbf{5 6} a$ was successfully confirmed by treatment with $\mathrm{H}_{2}$ and $\mathrm{Pd} / \mathrm{C}$ in methanol for $2 \mathrm{~d}$ in the presence of 2 drops of concentrated $\mathrm{HCl}$ followed by acetylation using $\mathrm{Ac}_{2} \mathrm{O}$ in pyridine. The compound, although obtained in low yield (10\%), had spectroscopic data ( ${ }^{1} \mathrm{H}$ and ${ }^{13} \mathrm{C} \mathrm{NMR}$ ) that closely matched those of known material 57.

56 $\alpha$ : Colourless oil. $R_{\mathrm{f}}=0.35(30 \%$ EtOAc/toluene $) \cdot[\alpha]_{D}^{25}=+47.5$ $\left(c=1, \mathrm{CHCl}_{3}\right)$. 'H NMR $\left(\mathrm{CDCl}_{3}, 400 \mathrm{MHz}\right): \delta=7.47(\mathrm{~s}, 1 \mathrm{H}$ triazole $\mathrm{H}), 7.30-7.12(\mathrm{~m}, 29 \mathrm{H}, \mathrm{Ar}-\mathrm{H}), 5.61$ and 5.14 (each d, each $J=14.8 \mathrm{~Hz}$, each $1 \mathrm{H}, N$-benzylic $\mathrm{H}), 4.91(\mathrm{~d}, J=13.2 \mathrm{~Hz}, 1 \mathrm{H}$, benzylic H), 4.87 (d, $J=10.0 \mathrm{~Hz}, 1 \mathrm{H}$, benzylic $\mathrm{H}), 4.79(\mathrm{~d}, J=$ $10.8 \mathrm{~Hz}, 1 \mathrm{H}$, benzylic $\mathrm{H}), 4.75(\mathrm{~d}, J=11.6 \mathrm{~Hz}, \mathrm{I} \mathrm{H}$, benzylic $\mathrm{H})$, $4.70(\mathrm{~d}, J=10.8 \mathrm{~Hz}, 1 \mathrm{H}$, benzylic $\mathrm{H}), 4.69$ and 4.63 (each d, each $J=11.2 \mathrm{~Hz}$, each $1 \mathrm{H}$, benzylic $\mathrm{H}), 4.58(\mathrm{~d}, J=12.0 \mathrm{~Hz}, 1 \mathrm{H}$, benzylic $\mathrm{H}), 4.51(\mathrm{~d}, J=12.0 \mathrm{~Hz}, 1 \mathrm{H}$, benzylic $\mathrm{H}), 4.50(\mathrm{~d}, J=$ $14.0 \mathrm{~Hz}, 1 \mathrm{H}$, benzylic $\mathrm{H}), 4.43(\mathrm{~d}, J=12.0 \mathrm{~Hz}, 1 \mathrm{H}$, benzylic $\mathrm{H})$, $4.38(\mathrm{~d}, J=4.0 \mathrm{~Hz}, 1 \mathrm{H}, 1 \mathrm{~b}-\mathrm{H}), 4.35(\mathrm{~d}, J=11.6 \mathrm{~Hz}, 1 \mathrm{H}$, benzylic H), $4.29(\mathrm{~d}, J=12.0 \mathrm{~Hz}, 1 \mathrm{H}$, benzylic $\mathrm{H}), 4.22(\mathrm{~d}, J=11.6 \mathrm{~Hz}, 1$ $\mathrm{H}$, benzylic $\mathrm{H}), 4.03(\mathrm{~d}, J=3.6 \mathrm{~Hz}, 1 \mathrm{H}, 1 \mathrm{a}-\mathrm{H}), 3.81$ (dd, $J=$ $9.2 \mathrm{~Hz}, 1 \mathrm{H}, 3 \mathrm{~b}-\mathrm{H}), 3.75$ (ddd, $J=8.8,2.0,1.2 \mathrm{~Hz}, 1 \mathrm{H}, 5 \mathrm{a}-\mathrm{H})$, $3.69(\mathrm{~m}, 1 \mathrm{H}, 5 \mathrm{~b}-\mathrm{H}), 4.65$ (d, $J=9.2 \mathrm{~Hz}, 1 \mathrm{H}, 3 \mathrm{a}-\mathrm{H}), 3.54-3.48(\mathrm{~m}$, $3 \mathrm{H}, 4 \mathrm{~b}-\mathrm{H}, 4 \mathrm{a}-\mathrm{H}, 6 \mathrm{a}-\mathrm{H}), 3.41$ (dd, $J=10.8,2.0 \mathrm{~Hz}, 1 \mathrm{H}, 6 \mathrm{~b}-\mathrm{H}$ ), $3.31(\mathrm{dd}, J=10.0,3.6 \mathrm{~Hz}, 1 \mathrm{H}, 2 \mathrm{a}-\mathrm{H}), 3.21\left(\mathrm{~s}, 3 \mathrm{H}, \mathrm{OCH}_{3}\right), 3.05$ (d, $J=9.6 \mathrm{~Hz}, 1 \mathrm{H}, 3 \mathrm{~b}-\mathrm{H}), 2.92-2.88\left(\mathrm{~m}, 2 \mathrm{H}, 6 \mathrm{~b}^{\prime}-\mathrm{H}, 2 \mathrm{~b}-\mathrm{H}\right) \mathrm{ppm}$. ${ }^{13} \mathrm{C}$ NMR (100 MHz): $\delta=147.09,139.44,139.09,138.82,138.78$, $138.30,138.12,135.55$ (Ar-Cq), 129.23, 128.67, 128.52, 128.50, $128.38,128.34,128.27,128.14,128.09,128.05,127.94,127.85$, $127.79,127.77,127.62,127.58,127.54,127.49,122.68$ (Ar-C), 97.53 (C-1a), 97.37 (C-1b), 83.65 (C-4b), 81.78 (C-3b), 81.78 (C-3a), 79.99 (C-2b), 79.12 (C-2a), 77.70 (C-4a), 75.90, 75.58, 74.89, 74.73, $73.26,73.12\left(\mathrm{OCH}_{2} \mathrm{Ar}\right), 69.97$ and $69.94(\mathrm{C}-5 \mathrm{~b}, \mathrm{C}-5 \mathrm{a}), 68.73(\mathrm{C}-$ 6b), 68.43 (C-6a), $66.28\left(\mathrm{OCH}_{2} \mathrm{Ar}\right), \quad 55.32\left(\mathrm{OCH}_{3}\right), \quad 54.14$ $\left(\mathrm{NCH}_{2} \mathrm{Ar}\right)$ ppm. HRMS (+ mode): calcd. for $\mathrm{C}_{59} \mathrm{H}_{65} \mathrm{~N}_{3} \mathrm{O}_{11}[\mathrm{M}+$ $\mathrm{H}]^{+} 990.4541$; found 990.4548 .

56p: Colourless oil. $R_{f}=0.30\left(30 \%\right.$ EtOAc/toluene). $[\alpha]_{D}^{25}=-13.5$ $\left(c=1, \mathrm{CHCl}_{3}\right)$. ${ }^{1} \mathrm{H} \mathrm{NMR}\left(\mathrm{CDCl}_{3}, 400 \mathrm{MHz}\right): \delta=7.61(\mathrm{~s}, 1 \mathrm{H}$, triazole $\mathrm{H}), 7.40-7.21(\mathrm{~m}, 28 \mathrm{H}, \mathrm{Ar}-\mathrm{H}), 6.93(\mathrm{~s}, 1 \mathrm{H}, \mathrm{Ar}-\mathrm{H}), 5.63$ and 5.59 (each d, each $J=16.0 \mathrm{~Hz}$, each $1 \mathrm{H}, N$-benzylic $\mathrm{H}$ ), 5.08 (d, $J=10.0 \mathrm{~Hz}, 1 \mathrm{H}$, benzylic H), $5.06(\mathrm{~d}, J=11.2 \mathrm{~Hz}, 1 \mathrm{H}$, benzylic $\mathrm{H}$ ), 4.95 (d, $J=11.2 \mathrm{~Hz}, 1 \mathrm{H}$, benzylic $\mathrm{H}$ ), 4.92 and 4.90 (each d, each $J=12.0 \mathrm{~Hz}$, each $1 \mathrm{H}$, benzylic $\mathrm{H}), 4.89-4.83(\mathrm{~m}, 2 \mathrm{H}$, benzylic $\mathrm{H}), 4.80(\mathrm{~d}, J=12.0 \mathrm{~Hz}, 1 \mathrm{H}$, benzylic $\mathrm{H}), 4.72(\mathrm{~d}, J=$ $12.0 \mathrm{~Hz}, 1 \mathrm{H}$, benzylic $\mathrm{H}$ ), $4.61-4.57$ (m, $3 \mathrm{H}$, benzylic $\mathrm{H}), 4.54$ (d, $J=12.0 \mathrm{~Hz}, 1 \mathrm{H}$, benzylic H), $4.53(\mathrm{~d}, J=3.6 \mathrm{~Hz}, 1 \mathrm{H}, 1 \mathrm{a}-\mathrm{H})$, $4.50(\mathrm{~d}, J=11.6 \mathrm{~Hz}, 1 \mathrm{H}$, benzylic $\mathrm{H}), 4.29(\mathrm{~d}, J=7.6 \mathrm{~Hz}, 1 \mathrm{H}$, lb-H), 3.96 (dd, $J=9.2 \mathrm{~Hz}, 1 \mathrm{H}, 3 \mathrm{~b}-\mathrm{H}), 3.69-3.62(\mathrm{~m}, 4 \mathrm{H}, 4 \mathrm{~b}-\mathrm{H}$, $\left.3 \mathrm{a}-\mathrm{H}, 5 \mathrm{~b}-\mathrm{H}, 6 \mathrm{a}^{\prime}-\mathrm{H}\right), 3.58(\mathrm{~d}, J=11.6 \mathrm{~Hz}, 1 \mathrm{H}, 6 \mathrm{~b}-\mathrm{H}), 3.51-3.45$ $(\mathrm{m}, 4 \mathrm{H}, 6 \mathrm{a}-\mathrm{H}, 4 \mathrm{a}-\mathrm{H}, 2 \mathrm{~b}-\mathrm{H}), 3.40-3.35(\mathrm{~m}, 5 \mathrm{H}, 2 \mathrm{a}-\mathrm{H}, 5 \mathrm{a}-\mathrm{H}$, $\left.\mathrm{OCH}_{3}\right)$ ppm. ${ }^{1.3} \mathrm{C}$ NMR $(100 \mathrm{MHz}): \delta=146.57,139.70,139.02$, $138.52,138.26,138.17,138.14,135.84$ (Ar-Cq) $128.70,128.56$, $128.45,128.41,128.02,128.01,127.90,127.72,127.56,127.52$, 126.82, 123.04 (Ar-C), 104.37 (C-1b), 97.92 (C-1a), 85.44 (C-3a), 82.25 (C-3b, C-2a), 80.22 (C-2b), 78.43 (C-4a), 77.65 (C-4b), 75.60, $75.32\left(\mathrm{OCH}_{2} \mathrm{Ar}\right), 75.11$ (C-5a), 74.94, 74.87, 73.38, 73.11 $\left(\mathrm{OCH}_{2} \mathrm{Ar}\right), 71.70(\mathrm{C}-6 \mathrm{~b}), 70.49(\mathrm{C}-5 \mathrm{~b}), 68.84(\mathrm{C}-6 \mathrm{a}), 65.69\left(\mathrm{OCH}_{2}\right)$, $55.32\left(\mathrm{OCH}_{3}\right), 53.54\left(\mathrm{NCH}_{2} \mathrm{Ar}\right) \mathrm{ppm}$. HRMS (+ mode): calcd. for $\mathrm{C}_{59} \mathrm{H}_{65} \mathrm{~N}_{3} \mathrm{O}_{11}[\mathrm{M}+\mathrm{H}]^{+} 990.4541$; found 990.4479 .

Compounds 65a,f: Compound $64(0.6 \mathrm{~g}, 0.546 \mathrm{mmol})$ on treatment with NIS (245 $\mathrm{mg}, 1.09 \mathrm{mmol})$ and TMSOTf $(25 \mu \mathrm{L}, 0.13 \mathrm{mmol})$ in dry $\mathrm{CH}_{2} \mathrm{Cl}_{2}(20 \mathrm{~mL})$ for $2 \mathrm{~h}$ and workup as described in general procedure $\mathrm{D}$ afforded an anomeric mixture of $65 a, \beta$ as a colourless oil (486 mg, 90\%) The pure isomers could not be separated $(\alpha / \beta=$ 3:1). $R_{t}=0.3$ ( $35 \%$ EtOAc/toluene). 'H NMR ( $\left.\mathrm{CDCl}_{3}, 400 \mathrm{MHz}\right)$ : $\dot{\partial}=7.61(\mathrm{~s}, 1 \mathrm{H}$, triazole $\mathrm{H}$, minor isomer $), 7.45-7.01(\mathrm{~m}, 30 \mathrm{H}$, triazole $\mathrm{H}$, major isomer, Ar-H, major and minor isomer), 5.62 (d, $J=14.4 \mathrm{~Hz}, 1 \mathrm{H}, N$-benzylic $\mathrm{H}$, minor isomer), 5.56 (d, $J=$ $14.0 \mathrm{~Hz}, 1 \mathrm{H}, N$-benzylic $\mathrm{H}$, major isomer), $5.47(\mathrm{~d}, J=14.0 \mathrm{~Hz}$, $1 \mathrm{H}, \mathrm{N}$-benzylic $\mathrm{H}$, major isomer), 5.42 (d, $J=14.4 \mathrm{~Hz}, 1 \mathrm{H}, \mathrm{N}$ benzylic $\mathrm{H}$, minor isomer), 5.09 (d, $J=10.8 \mathrm{~Hz}, 1 \mathrm{H}$, benzylic $\mathrm{H}$, major isomer), $5.02(\mathrm{~d}, J=12.8 \mathrm{~Hz}, 1 \mathrm{H}$, benzylic $\mathrm{H}$, minor isomer), 4.87 (d, $J=10.8 \mathrm{~Hz}, 1 \mathrm{H}$, benzylic $\mathrm{H}$, major isomer), 4.86 (d, $J=10.4 \mathrm{~Hz}, 1 \mathrm{H}$, benzylic $\mathrm{H}$, minor isomer), $4.81(\mathrm{~d}, J=10.8 \mathrm{~Hz}, 1$ $\mathrm{H}$, benzylic $\mathrm{H}$, minor isomer), $4.79(\mathrm{~d}, J=11.6 \mathrm{~Hz}, 1 \mathrm{H}$, benzylic 
$\mathrm{H}$, major isomer), 4.76-4.63 (m, 5 benzylic $H$ for each major and minor isomer, $\mathrm{I} \mathrm{H}$, benzylic $\mathrm{H}$ for minor isomer), $4.61-4.53(\mathrm{~m}, 2$ $\mathrm{H}$, benzylic $\mathrm{H}$ for each major and minor isomer), 4.52-04.50 (m, 1 $\mathrm{H}$, for $\mathrm{lb}-\mathrm{H}$ major isomer, $J=5.6 \mathrm{~Hz}$ and $\mathrm{lb}-\mathrm{H}$ for minor isomer $J=9.2 \mathrm{~Hz}), 4.48-4.34(\mathrm{~m}, 2$ benzylic $\mathrm{H}$ for each major and minor isomer, $1 \mathrm{H}$, benzylic $\mathrm{H}$ for major isomer $), 4.30(\mathrm{~d}, J=4.8 \mathrm{~Hz}, 1$ $\mathrm{H}, 1 \mathrm{a}-\mathrm{H}$, minor isomer), $4.25(\mathrm{~d}, J=12.8 \mathrm{~Hz}, 1 \mathrm{H}$, benzylic $\mathrm{H}$, minor isomer), 4.19 (d, $J=3.2 \mathrm{~Hz}, 1 \mathrm{H}, \mathrm{la}-\mathrm{H}$, major isomer), 4.10 (d, $J=12.0 \mathrm{~Hz}, 1 \mathrm{H}$, benzylic $\mathrm{H}$, minor isomer), 4.06 (dd, $J=12.8$, $2.4 \mathrm{~Hz}, 1 \mathrm{H}, 6 \mathrm{a}-\mathrm{H}$, major isomer), $3.96(\mathrm{dd}, J=9.2 \mathrm{~Hz}, 1 \mathrm{H}, 3 \mathrm{~b}-$ $\mathrm{H}$, minor isomer), $3.88(\mathrm{~m}, 1 \mathrm{H}, 5 \mathrm{~b}-\mathrm{H}$, minor isomer), $3.86(\mathrm{~m}, 1$ $\mathrm{H}, 5 \mathrm{a}-\mathrm{H}$, minor isomer), 3.82 and 3.80 (each dd, each $J=9.2 \mathrm{~Hz}$, $3 \mathrm{~b}-\mathrm{H}, 3 \mathrm{a}-\mathrm{H}$, major isomer), 3.72 (dd, $J=10.4,5.6 \mathrm{~Hz}, 4 \mathrm{a}-\mathrm{H}$, minor isomer), $3.60-3.40(\mathrm{~m}, 13 \mathrm{H}, 5 \mathrm{~b}-\mathrm{H}$, major isomer, $4 \mathrm{~b}-\mathrm{H}$, major isomer, $3 \mathrm{a}-\mathrm{H}$, minor isomer, $5 \mathrm{a}-\mathrm{H}$, major isomer, $4 \mathrm{a}-\mathrm{H}$, major isomer, 2a-H major isomer, $4 \mathrm{~b}-\mathrm{H}$, minor isomer, $6 \mathrm{~b}-\mathrm{H}$, minor isomer, $6 \mathrm{~b}$ $\mathrm{H}, 6 \mathrm{a}^{\prime}-\mathrm{H}, 6 \mathrm{~b}^{\prime}-\mathrm{H}$, major isomer), 3.32-3.31 (m, $4 \mathrm{H}, 2 \mathrm{a}-\mathrm{H}$ of minor isomer merged with $\mathrm{OCH}_{3}$ of major isomer), $3.28\left(\mathrm{~s}, 3 \mathrm{H}, \mathrm{OCH}_{3}\right.$, minor isomer), 3.23 (dd, $J=9.2,3.6 \mathrm{~Hz}, 1 \mathrm{H}, 2 \mathrm{~b}-\mathrm{H}$, major isomer) ppm. ${ }^{13} \mathrm{C}$ NMR $(100 \mathrm{MHz}): \delta=145.31,145.30,139.35$, $139.31,139.03,138.68,138.38,138.33,138.22,138.13,138.10$, $138.06,136.72,133.03,132.07,131.81,131.69,131.35,131.23$, $129.62,129.34,129.19,128.92,128.46,128.41,128.37,128.35$, $128.32,128.21,128.03,127.99,127.95,127.72,127.60,127.55$, $127.40,127.38,127.22,124.65,123.47$ (Ar-C, major and minor isomer), 101.61 ( $\mathrm{C}-1 \mathrm{~b}$, minor isomer), 98.34 ( $\mathrm{C}-1 \mathrm{~b}$, major isomer), 97.74, (C-1a, minor isomer), 97.13, (C-1a, major isomer), 85.41, $81.92,81.91,80.41,80.26,80.25,78.96,78.85,78.19,77.84,75.83$, $75.33,75.32,74.97,74.90,74.46,73.63,73.38,73.33,73.25,72.08$ $71.29,71.12,70.44,69.48,69.09,68.83,66.17$ (C-6b, minor isomer), 65.65 (C-6a, major isomer), $55.54\left(\mathrm{OCH}_{3}\right.$, major isomer), 55.06 $\left(\mathrm{OCH}_{3}\right.$, minor isomer), $52.69(\mathrm{NCH}, \mathrm{Ar}$, minor isomer), 52.05 ( $\mathrm{NCH}_{2} \mathrm{Ar}$, major isomer) ppm. HRMS (+ mode): calcd. for $\mathrm{C}_{59} \mathrm{H}_{65} \mathrm{~N}_{3} \mathrm{O}_{11}[\mathrm{M}+\mathrm{H}]^{+}$990.4541; found 990.4547 .

Compounds 70ce and 70p: Compound 69 (250 mg, $0.227 \mathrm{mmol})$ on treatment with NIS $(101 \mathrm{mg}, 0.455 \mathrm{mmol})$ and TMSOTf $(25 \mu \mathrm{L}$, $0.13 \mathrm{mmol})$ in dry $\mathrm{CH}_{2} \mathrm{Cl}_{2}(15 \mathrm{~mL})$ for $2 \mathrm{~h}$ and workup as described in general procedure D afforded $70 \alpha$ and $70 \beta$ as a colourless oil ( $185 \mathrm{mg}, 82 \%, \alpha / \beta=1: 2$ ). The two compounds were successfully separated in pure form and characterized by their comparative spectroscopic data.

70 $\alpha: R_{\mathrm{f}}=0.32$ (30\% EtOAc/toluene). $[a]_{\mathrm{i}}^{25}=+27.2\left(c=1, \mathrm{CHCl}_{3}\right)$ ${ }^{1} \mathrm{H}$ NMR $\left(\mathrm{CDCl}_{3}, 400 \mathrm{MHz}\right): \delta=7.73(\mathrm{~s}, 1 \mathrm{H}$, triazole $\mathrm{H}), 7.30$ $7.15(\mathrm{~m}, 29 \mathrm{H}, \mathrm{Ar}-\mathrm{H}), 7.12(\mathrm{~s}, 1 \mathrm{H}, \mathrm{Ar}-\mathrm{H}), 7.10$ and 7.08 (each d, each $J=8.0 \mathrm{~Hz}$, each $1 \mathrm{H}, \mathrm{Ar}-\mathrm{H}), 7.02(\mathrm{~d}, J=8.0 \mathrm{~Hz}, 1 \mathrm{H}, \mathrm{Ar}-$ $\mathrm{H}), 5.59$ and 5.22 (each d, each $J=15.2 \mathrm{~Hz}$, each $1 \mathrm{H}, N$-benzylic H) , 4.98, 4.91, 4.86, 4.82, 4.79 and 4.77 (each d, each $J=12.0 \mathrm{~Hz}$, each $1 \mathrm{H}$, benzylic $\mathrm{H}), 4.71-4.65(\mathrm{~m}, 1 \mathrm{H}$, benzylic $\mathrm{H}), 4.55(\mathrm{~d}, J$ $=12.0 \mathrm{~Hz}, 1 \mathrm{H}$, benzylic H), $4.52(\mathrm{~d}, J=4.0 \mathrm{~Hz}, 1 \mathrm{H}, 1 \mathrm{a}-\mathrm{H}), 4.49$ (d, $J=4.0 \mathrm{~Hz}, 1 \mathrm{H}, \mathrm{lb}-\mathrm{H}), 4.42(\mathrm{~d}, J=12.0 \mathrm{~Hz}, 1 \mathrm{H}$, benzylic H), 4.35 and 4.31 (each d, each $J=12.8 \mathrm{~Hz}$, each $1 \mathrm{H}$, benzylic $\mathrm{H}$ ), $4.23(\mathrm{~d}, J=12.0 \mathrm{~Hz}, 1 \mathrm{H}$, benzylic $\mathrm{H}$ ), 4.07 and 4.05 (each dd, each $J=9.6 \mathrm{~Hz}$, each $1 \mathrm{H}, 3 \mathrm{~b}-\mathrm{H}, 3 \mathrm{a}-\mathrm{H}), 3.93(\mathrm{~d}, J=9.6 \mathrm{~Hz}, 1 \mathrm{H}$, $4 \mathrm{~b}-\mathrm{H}), 3.66$ (dd, $J=12.0,4.0 \mathrm{~Hz}, 1 \mathrm{H}, 6 \mathrm{a}-\mathrm{H}), 3.59-3.50(\mathrm{~m}, 2 \mathrm{H}$, $5 \mathrm{~b}-\mathrm{H}, 5 \mathrm{a}-\mathrm{H}), 3.49\left(\mathrm{dd}, J=8.8 \mathrm{~Hz}, 1 \mathrm{H}, 6 \mathrm{a}^{\prime}-\mathrm{H}\right), 3.45(\mathrm{~d}, J=$ $12.0 \mathrm{~Hz}, 1 \mathrm{H}, 6 \mathrm{~b}-\mathrm{H}), 3.37-3.30\left(\mathrm{~m}, 3 \mathrm{H}, 6 \mathrm{~b}^{\prime}-\mathrm{H}, 2 \mathrm{a}-\mathrm{H}, 4 \mathrm{a}-\mathrm{H}\right), 3.17-$ $3.12(\mathrm{~m}, 4 \mathrm{H}, 2 \mathrm{~b}-\mathrm{H}, 4 \mathrm{a}-\mathrm{H}), 3.17-3.12\left(\mathrm{~m}, 5 \mathrm{H}, \mathrm{OCH}_{3}, 3 \mathrm{~b}-\mathrm{H}, 4 \mathrm{a}-\right.$ H) ppm. ${ }^{13} \mathrm{C}$ NMR $(100 \mathrm{MHz}): \delta=139.96,138.66,138.18,138.13$, $138.06,137.99,137.93,135.65$ (Ar-Cq), 128.72, 128.49, 128.45, $128.40,128.36,128.26,128.17,127.99,127.96,127.84,127.80$, 127.66, 127.62, 127.59, 127.36, 127.21, 127.22, 124.04 (Ar-C), 97.72 (C-1b), 97.63 (C-1a), 86.32 (C-5b), 80.99 (C-5a), 78.43 (C-2b), 77.98 (C-2a), 75.89 (C-4a), 75.46 (C-3b), 75.38 (C-3a), 74.88, 74.79,
$74.64,73.45,73.34$ and $72.86\left(\mathrm{OCH}_{2} \mathrm{Ar}\right), 69.20(\mathrm{C}-6 \mathrm{a}), 68.95(\mathrm{C}-$ 6b), 68.74 (C-4b), $65.44 \quad\left(\mathrm{CH}_{2} \mathrm{Ar}\right), \quad 55.08 \quad\left(\mathrm{OCH}_{3}\right), \quad 53.99$ ( $\mathrm{NCH}_{2} \mathrm{Ar}$ ) ppm. HRMS (+ mode): calcd. for $\mathrm{C}_{59} \mathrm{H}_{65} \mathrm{~N}_{3} \mathrm{O}_{11}[\mathrm{M}+$ $\mathrm{H}]^{+}$990.4541; found 990.4167 .

70ß: $R_{i}=0.41\left(30 \%\right.$ EtOAc/toluene). $[a]_{\mathrm{D}}^{25}=-9.4\left(c=1, \mathrm{CHCl}_{3}\right)$ ${ }^{1} \mathrm{H}$ NMR $\left(\mathrm{CDCl}_{3}, 400 \mathrm{MHz}\right): \delta=7.70(\mathrm{~s}, 1 \mathrm{H}$, triazole $\mathrm{H}), 7.32$ $(\mathrm{m}, 23 \mathrm{H}, \mathrm{Ar}-\mathrm{H}), 7.12(\mathrm{dd}, J=8.0,1.6 \mathrm{~Hz}, 2 \mathrm{H}, \mathrm{Ar}-\mathrm{H}), 6.98(\mathrm{~d}, J$ $=8.0 \mathrm{~Hz}, 1 \mathrm{H}, \operatorname{Ar}-\mathrm{H}), 6.63(\mathrm{~s}, 1 \mathrm{H}, \operatorname{Ar}-\mathrm{H}), 5.72(\mathrm{~d}, J=12.0 \mathrm{~Hz}, 1$ $\mathrm{H}$, benzylic $\mathrm{H}), 5.35(\mathrm{~d}, J=12.8 \mathrm{~Hz}, 1 \mathrm{H}$, benzylic $\mathrm{H}), 5.20(\mathrm{~d}, J$ $=10.8 \mathrm{~Hz}, 1 \mathrm{H}$, benzylic $\mathrm{H}), 8.77-8.74(\mathrm{~m}, 4 \mathrm{H}$, benzylic $\mathrm{H}), 4.70$ (d, $J=12.0 \mathrm{~Hz}, 1 \mathrm{H}$, benzylic $\mathrm{H}$ ), $4.61(\mathrm{~d}, J=12.0 \mathrm{~Hz}, 1 \mathrm{H}$, benzylic $\mathrm{H}), 4.53(\mathrm{~d}, J=12.0 \mathrm{~Hz}, 1 \mathrm{H}$, benzylic $\mathrm{H}), 4.46(\mathrm{~d}, J=4.0 \mathrm{~Hz}$, $1 \mathrm{H}, 1 \mathrm{a}-\mathrm{H}), 4.44(\mathrm{~d}, J=8.0 \mathrm{~Hz}, 1 \mathrm{H}, 1 \mathrm{~b}-\mathrm{H}), 4.42(\mathrm{~d}, J=12.0 \mathrm{~Hz}$, $1 \mathrm{H}$, benzylic $\mathrm{H}), 4.41(\mathrm{~d}, J=12.0 \mathrm{~Hz}, 1 \mathrm{H}$, benzylic $\mathrm{H}), 4.39$ (d, $J=12.0 \mathrm{~Hz}, 1 \mathrm{H}$, benzylic $\mathrm{H}), 4.38-4.29(\mathrm{~m}, 4 \mathrm{H}, 6 \mathrm{a}-\mathrm{H}$ merged with 3 benzylic $\mathrm{H}), 3.94-3.88(\mathrm{~m}, 2 \mathrm{H}, 3 \mathrm{~b}-\mathrm{H}, 5 \mathrm{a}-\mathrm{H}), 3.80-3.72(\mathrm{~m}$, $2 \mathrm{H}, 3 \mathrm{a}-\mathrm{H}, 5-\mathrm{H}), 3.54(\mathrm{dd}, J=12.0,1.6 \mathrm{~Hz}, 1 \mathrm{H}, 6 \mathrm{~b}-\mathrm{H}), 3.48-3.36$ $\left(\mathrm{m}, 4 \mathrm{H}, 6 \mathrm{a}^{\prime}-\mathrm{H}, 4 \mathrm{a}-\mathrm{H}, 2 \mathrm{a}-\mathrm{H}, 6 \mathrm{~b}^{\prime}-\mathrm{H}\right), 3.35(\mathrm{~d}, J=9.2 \mathrm{~Hz}, 1 \mathrm{H}, 4 \mathrm{a}-$ $\mathrm{H}), 3.27\left(\mathrm{~s}, 3 \mathrm{H}, \mathrm{OCH}_{3}\right), 3.24(\mathrm{~d}, J=4.0 \mathrm{~Hz}, 1 \mathrm{H}, 2 \mathrm{a}-\mathrm{H}) \mathrm{ppm} .{ }^{13} \mathrm{C}$ NMR $(100 \mathrm{MHz}): \delta=146.71,140.08,140.01,138.82,138.53$, $138.13,138.10,135.57$ (Ar-Cq), 128.41, 128.40, 128.39, 128.38, $128.35,128.32,128.31,128.10,127.99,127.97,127.75,127.74$, $127.69,127.68,127.35,127.34,125.72,124.45,124.03$ (Ar-C), 101.28 (C-1b), 98.02 (C-1a), 82.25 (C-3b), 81.28 (C-3a), 80.67 (C5b), 79.21 (C-2a), 78.74 (C-4b), 78.25 (C-2b), 75.96, 75.73, 75.06, $73.51,73.39,72.60\left(\mathrm{OCH}_{2} \mathrm{Ar}\right), 71.21(\mathrm{C}-5 \mathrm{~b}), 70.69(\mathrm{C}-4 \mathrm{a}), 69.72$ (C-6a), 69.59 (C-6b), $65.01 \quad\left(\mathrm{OCH}_{2}\right), 55.33\left(\mathrm{OCH}_{3}\right), 53.48$ $\left(\mathrm{NCH}_{2} \mathrm{Ar}\right) \mathrm{ppm}$. HRMS: HRMS ( + mode): calcd. for $\mathrm{C}_{59} \mathrm{H}_{65} \mathrm{~N}_{3} \mathrm{O}_{11}\left[\mathrm{M}+\mathrm{H}^{+}\right.$990.4541; found 990.4168 .

Compound 77a: Compound $76(0.4 \mathrm{~g}, 0.357 \mathrm{mmol})$ on treatment with NIS (160 mg, $0.715 \mathrm{mmol})$ and TMSOTf $(45 \mu \mathrm{L}, 0.24 \mathrm{mmol})$ in dry $\mathrm{CH}_{2} \mathrm{Cl}_{2}$ for $2 \mathrm{~h}$ and workup as described in general procedure $\mathrm{D}$ afforded $77 a$ as a colourless oil $(0.19 \mathrm{~g}, 55 \%) . R_{\mathrm{f}}=0.33$ $(30 \%$ EtOAc/toluene $) .[a]_{15}^{25}=+1.5\left(c=1, \mathrm{CHCl}_{3}\right) .{ }^{\mathrm{i}} \mathrm{H} \mathrm{NMR}$ $\left(\mathrm{CDCl}_{3}, 400 \mathrm{MHz}\right): \delta=7.96(\mathrm{~d}, J=8.0 \mathrm{~Hz}, 2 \mathrm{H}, \mathrm{Ar}-\mathrm{H}), 7.50-7.37$ $(\mathrm{m}, 5 \mathrm{H}, \mathrm{Ar}-\mathrm{H}), 7.34-7.11(\mathrm{~m}, 22 \mathrm{H}$, triazole $\mathrm{H}, \mathrm{Ar}-\mathrm{H}), 7.01 \mathrm{dd}$, $J=8.4,2.0 \mathrm{~Hz}, 1 \mathrm{H}, \mathrm{Ar}-\mathrm{H}$ ), 5.88 and 5.57 (each d, each $J=$ $14.8 \mathrm{~Hz}$, each $1 \mathrm{H}, N$-benzylic $\mathrm{H}$ ), 4.85 and 4.83 (each d, each $J=$ $10.8 \mathrm{~Hz}$, each $1 \mathrm{H}$, benzylic $\mathrm{H}), 4.79(\mathrm{~d}, J=10.8 \mathrm{~Hz}, 1 \mathrm{H}$, benzylic H), $4.74(\mathrm{~d}, J=11.2 \mathrm{~Hz}, 1 \mathrm{H}$, benzylic H), $4.72-4.66(\mathrm{~m}, 3 \mathrm{H}, 6 \mathrm{a}-$ $\mathrm{H}$ merged with benzylic $\mathrm{H}), 4.66(\mathrm{~d}, J=12.0 \mathrm{~Hz}, 1 \mathrm{H}$, benzylic $\mathrm{H})$, $4.62(\mathrm{~d}, J=4.0 \mathrm{~Hz}, 1 \mathrm{H}, \mathrm{lb}-\mathrm{H}), 4.57$ and 4.53 (each d, each $J=$ $12.0 \mathrm{~Hz}$, each $1 \mathrm{H}$, benzylic $\mathrm{H}), 4.51-4.48(\mathrm{~m}, 3 \mathrm{H}, \mathrm{la}-\mathrm{H}$, benzylic $\mathrm{H}), 5.45(\mathrm{~d}, J=10.8 \mathrm{~Hz}, 1 \mathrm{H}$, benzylic H), $5.43(\mathrm{~d}, J=10.4 \mathrm{~Hz}, 1$ $\mathrm{H}$, benzylic $\mathrm{H}), 3.76-3.71(\mathrm{~m}, 2 \mathrm{H}, 5 \mathrm{a}-\mathrm{H}, 3 \mathrm{a}-\mathrm{H}), 3.67(\mathrm{dd}, J=11.2$, $2.0 \mathrm{~Hz}, 1 \mathrm{H}, 6 \mathrm{~b}-\mathrm{H}), 3.66-3.57\left(\mathrm{~m}, 3 \mathrm{H}, 6 \mathrm{~b}^{\prime}-\mathrm{H}, 5 \mathrm{~b}-\mathrm{H}, 4 \mathrm{~b}-\mathrm{H}\right), 3.55$ (dd, $J=9.6 \mathrm{~Hz}, 1 \mathrm{H}, 3 \mathrm{~b}-\mathrm{H}), 3.49-3.38(\mathrm{~m}, 3 \mathrm{H}, 2 \mathrm{~b}-\mathrm{H}, 2 \mathrm{a}-\mathrm{H}, 4 \mathrm{a}-$ $\mathrm{H}), 3.28\left(\mathrm{~s}, 3 \mathrm{H}, \mathrm{OCH}_{3}\right) \mathrm{ppm} .{ }^{13} \mathrm{C}$ NMR $(100 \mathrm{MHz}): \delta=166.91$ $(\mathrm{COPh}), 145.31,138.61,138.36,138.32,138.10,136.02,134.25$, $133.23,131.93,130.28,129.81,127.51,129.16,128.92,128.86$, $128.63,128.48,128.45,128.37,128.27,128.00,127.93,127.82$, $127.72,127.88,127.59,127.48,123.00(\mathrm{Ar}-\mathrm{C}), 97.73(\mathrm{C}-\mathrm{Ib}), 97.72$ (C-1a), 87.12 (C-3a), 86.57 (C-3b), 81.21 (C-2b), 80.95 (C-2a), 80.12 (C-4b), 79.17 (C-4a), 76.77, 75.77, 75.59, 75.06, 73.45, 71.13 $\left(\mathrm{CH}_{2} \mathrm{Ar}\right), 70.39$ (C-5a), $67.62(\mathrm{C}-5 \mathrm{~b}), 66.72,63.73(\mathrm{C}-6 \mathrm{~b}, \mathrm{C}-6 \mathrm{a})$, $55.13\left(\mathrm{OCH}_{3}\right), 50.98\left(\mathrm{NCH}_{2} \mathrm{Ar}\right)$ ppm. HRMS ( + mode): calcd. for $\mathrm{C}_{59} \mathrm{H}_{63} \mathrm{~N}_{3} \mathrm{O}_{12}[\mathrm{M}+\mathrm{H}]^{+}$1004.4334; found 1004.4298.

Supporting Information (see footnote on the first page of this article): Synthetic methods for all donors, acceptors and intermediates required to investigate the intramolecular glycosylation reactions and the ${ }^{1} \mathrm{H}$ and ${ }^{13} \mathrm{C}$ NMR spectra of all the synthesized compounds 


\section{Acknowledgments}

This work was supported by the Universitat Konstanz, Germany. The authors thank Dr. Vipin Kumar, Anna-Lena Steck, and Norman Hardt for their help in measuring $H R$ mass spectrometric data.

[1] A. Varki, Glycobiology 1993, 3, 97-130.

[2] a) H. Lis, N. Sharon, Chem. Rev. 1998, 98, 637-674; b) C. R. Bertozzi, L. L. Kiessling, Science 2001, 291, 2357-2364; c) P. M. Rudd, T. Elliott, P. Cresswell, I. A. Wilson, R. A. Dwek, Science 2001, 291, 2370-2376.

[3] a) T. Angata, A. Varki, Chen. Rev. 2002, 102, 439-470; b) R. A. Dwek, Chem. Rev 1996, 96, 683-720.

[4] A. Giannis, Angew. Chem. 1994, 106, 188; Angew. Chem. Int. Ed. Engl. 1994, 33, 178-180.

[5] R. R. Schmidt, Angew. Chem. 1986, 98, 213; Angew. Chem. Int. Ed. Engl. 1986, 25, 212-235.

[6] R. R. Schmidt, W. Kinzy, Adv. Carbohydr: Chem. Biochem. 1994, 50, 21-123.

[7] X. Zhu, R. R. Schmidt, Angew. Chem. 2009, 121, 1932; Angew. Chem. Int. Ed. 2009, 48, 1900-1935.

[8] R. S. McGavin, R. A. Gagne, M. C. Chervenak, D. R. Bundle, Org. Biomol. Chem. 2005, 3, 2723-2732.

[9] a) J. C. Morales, D. Zurita, S. Penades, J. Org. Chem. 1998, 63, 9212-9222; b) J. M. Coteron, C. Went, C. Bossos, S. Penades, J. Am. Chem. Soc: 1993, 115, 10066-10076.

[10] a) J. Szejtli, Pure Appl. Chem. 2004, 76, 1825-1845; b) K. D. Bodine, D. Y. Gin, M. S. Gin, J. Am. Chem. Soc. 2004, 126 $1638-1639$; c) R. Leyden, P. V. Murphy, Synlett 2009, 12, 1949 1950 ; d) K. D. Bodine, D. Y. Gin, M. S. Gin, Org. Lett. 2005 , 7, 4479-4482.

[11] a) T. Velasco-Torrijos, P. V. Murphy, Org. Lett. 2004, 6, 3961 3964; b) M. Fiore, A. Chambery, A. Marra, A. Dondoni, Org Biomol. Chem. 2009, 7, 3910-3913; c) L. Moni, S. Rossetti, M. Scoponi, A. Marra, A. Dondoni, Chem. Commun. 2010, 46 475 477; d) C. Coppola, A. Paciello, G. Mangiapia, S. Licen, M. Boccalon, L. De Napoli, L. Paduano, P. Tecilla, D. Montesarchio, Chem. Eur: J. 2010, 16, 13757-13772.

[12] M. Gening, D. Titov, A. Grachev, A. Gerbst, O. Yudina, A. Shashkov, A. Chizhov, Y. Tsvetkov, N. Nifantiev, Eur. J. Org. Chem. 2010, 2465-2475.

[13] R. R. Schmidt, K.-H. Jung, Carbohydr. Eur. 1999, 27, 12-21.

[14] P. Fugedi, D. E. Levy (Eds.), The Organic Chemistry of Sugars, Taylor \& Francis, USA, 2006.

[15] K. H. Jung, M. Müller, R. R. Schmidt, Chem. Rev. 2000, 100 , $4423-4442$.

[16] M. Müller, U. Huchel, A. Geyer, R. R. Schmidt, J. Org. Chem. 1999, 64, 6190-6201.
[17] a) G. Scheffler, R. R. Schmidt, Tetrahedron Lett. 1997, 38, 2943-2946; b) U. Huchel, R. R. Schmidt, Tetrahedron Lett. $1995,36,1417-1420$.

[18] M. E. Behrendt, R. R. Schmidt, Tetrahedron Lett. 1993, 34, 6733-6736.

[19] Y. Ito, Y. Ohnishi, T. Ogawa, Y. Nakahara, Synlett 1998, 1102 1104

[20] a) U. Huchel, R. R. Schmidt, Tetrahedron Lett. 1998, 39, 7693 7694 ; b) G. Scheffler, R. R. Schmidt, J. Org. Chem. 1999, 64, 1319-1325.

[21] a) A. V. Demchenko, Synlett 2003, 1225-1240; b) A. J. Fairbanks, Synlett 2003, 1945-1958; c) M. Wakao, K. Fukase, S. Kusumoto, J. Org. Chem. 2002, 67, 8182-8190; d) M. R. Pratt, C. D. Leigh, C. R. Bertozzi, Org. Lett. 2003, 5, 3185-8188; e) I. Cumpstey, K. Chayajarus, A. J. Fairbanks, A. J. Redgraveb, C. M. P. Seward, Tetrahedron: Asymmetry 2004, 15, 3207-3221; f) M. Aloui, D. J. Chambers, I. Cumpstey, A. J. Fairbanks, A. J. Redgrave, C. M. P. Seward, Chem. Eur. J. 2002, 8, 2608-2621.

[22] M. Müller, R. R. Schmidt, Eur. J. Org. Chem. 2001, 2055-2066.

[23] T. Ziegler, R. Lau, Tetrahedron Lett. 1995, 36, 1417-1420.

[24] T. Ziegler, G. Lemanski, Eur: J. Org. Chem. 2000, 181-186.

[25] R. J. Tennant-Eyles, B. G. Davis, J. A. Fairbanks, Chem. Commun. 1999, 1037-1038.

[26] S. Valverde, M. Garcia, A. M. Gomez, J. C. Lopez, Synlett 2000, 22-26.

[27] M. Wakao, K. Fukase, S. Kusumoto, Synlett 1999, 1911-1914.

[28] G. Stork, G. Kim, J. Am. Chem. Soc. 1992, 114, 1087-1088.

[29] a) F. W. Lichtenthaler, T. J. Schneider-Adams, J. Org. Chem. 1994, 59, 6728-6734; b) M. Aloui; D. J. Chambers, I. Cumpstey, A. J. Fairbanks, A. J. Redgrave, C. M. P. Seward, Chem. Eur. J. 2002, 8, 2608-2621; c) V. Pozsgay, H. J. Jennings, Synthesis 1990, 724.

[30] a) D. Rabuka, S. C. Hubbard, S. T. Laughlin, S. P. Argade, C. R. Bertozzi, J. Am. Chent. Soc. 2006, 128, 12078-12079; b) P. Cheshev, A. Marra, A. Dondoni, Org. Biomol. Chem. 2006, 4, 3225-3227; c) P. Wu, M. Malkoch, J. N. Hunt, R. Vestberg, E. Kaltgrad, M. G. Finn, V. V. Fokin, K. B. Sharpless, C. J. Hawker, Chem. Commun. 2005, 5775-5777; d) Y. J. Gao, A. Eguchi, K. Kakehi, Y. C. Lee, Bioorg. Med. Chem. 2005, 13, 6151-6157; e) M. C. Bryan, F. Fazio, H. Lee, C.-Y. Huang, A. Chang, M. D. Best, D. A. Calarese, O. Blixt, J. C. Paulson, D. Burton, I. A. Wilson, C.-H. Wong, J. Am. Chem. Soc. 2004, $126,8640-8641$; f) S. Muthana, H. Yu, H. Cao, J. Cheng, X. Chen, J. Org. Chem. 2009, 74, 2928-2936.

[31] Note added during revision of the paper: Model studies with methyl 2,3,4-tri- $O$-benzyl-6-O-(1-phenyl-1,2,3-triazolyl-4-ylmethyl)- $\alpha$-D-glucopyranoside revealed that under Birch reduction conditions ( $\mathrm{Na}$ in liquid ammonia, $-78^{\circ} \mathrm{C}, 40 \mathrm{~min}$ ) complete removal of the $O$-benzyl and the $O$-triazolylmethyl groups is possible.

[32] P. J. Garegg, T. Iversen, S. Oscarson, Carbohydr. Res. 1976, 50, C12-14.

[33] D. J. Bell, J. Lorber, J. Chem. Soc. 1940, 453-455. 